\title{
Innovative Preservation Methods Improving the Quality and Safety of Fish Products: Beneficial Effects and Limits
}

\author{
Barbara Speranza ${ }^{1}$, Angela Racioppo ${ }^{1} \mathbb{D}$, Antonio Bevilacqua ${ }^{1}\left(\mathbb{D}\right.$, Veronica Buzzo ${ }^{2}$, Piera Marigliano ${ }^{2}$, \\ Ester Mocerino $^{2}$, Raffaella Scognamiglio ${ }^{2}$, Maria Rosaria Corbo ${ }^{1}$ (D), Gennaro Scognamiglio ${ }^{2, *}$ \\ and Milena Sinigaglia $1, *$
}

Citation: Speranza, B.; Racioppo, A.; Bevilacqua, A.; Buzzo, V.; Marigliano, P.; Mocerino, E.; Scognamiglio, R.; Corbo, M.R.; Scognamiglio, G.; Sinigaglia, M. Innovative Preservation Methods Improving the Quality and Safety of Fish Products: Beneficial Effects and Limits. Foods 2021, 10, 2854. https://doi.org/ 10.3390 /foods 10112854

Academic Editors: Anita Jakobsen and Foteini F. Parlapani

Received: 24 September 2021 Accepted: 15 November 2021 Published: 18 November 2021

Publisher's Note: MDPI stays neutral with regard to jurisdictional claims in published maps and institutional affiliations.

Copyright: (c) 2021 by the authors. Licensee MDPI, Basel, Switzerland. This article is an open access article distributed under the terms and conditions of the Creative Commons Attribution (CC BY) license (https:/ / creativecommons.org/licenses/by/ $4.0 /)$.
1 Department of Agriculture Food, Natural Resources and Engineering (DAFNE), University of Foggia, Via Napoli 25, 71122 Foggia, Italy; barbara.speranza@unifg.it (B.S.); angela.racioppo@unifg.it (A.R.); antonio.bevilacqua@unifg.it (A.B.); mariarosaria.corbo@unifg.it (M.R.C.)

2 UNCI AGROALIMENTARE, Via San Sotero 32, 00165 Roma, Italy; veronicabuzzo@gmail.com (V.B.); marigliano.piera@libero.it (P.M.); estermocerino3@gmail.com (E.M.); raffaella-rs@libero.it (R.S.)

* Correspondence: consulentescognamigliog@gmail.com or unciagroalimentare@libero.it (G.S.); milena.sinigaglia@unifg.it (M.S.); Tel.: +39-06-6380822 (G.S.); +39-0881-589233 (M.S.)

\begin{abstract}
Fish products are highly perishable, requiring proper processing to maintain their quality and safety during the entire storage. Different from traditional methods used to extend the shelf-life of these products (smoking, salting, marinating, icing, chilling, freezing, drying, boiling, steaming, etc.), in recent years, some alternative methods have been proposed as innovative processing technologies able to guarantee the extension of their shelf-life while minimally affecting their organoleptic properties. The present review aims to describe the primary mechanisms of some of these innovative methods applied to preserve quality and safety of fish products; namely, non-thermal atmospheric plasma (NTAP), pulsed electric fields (PEF), pulsed light (PL), ultrasounds (US) and electrolyzed water (EW) are analysed, focusing on the main results of the studies published over the last 10 years. The limits and the benefits of each method are addressed in order to provide a global overview about these promising emerging technologies and to facilitate their greater use at industrial level. In general, all the innovative methods analysed in this review have shown a good effectiveness to control microbial growth in fish products maintaining their organoleptic, nutritional and sensory characteristics. Most of the technologies have also shown the great advantage to have a lower energy consumption and shorter production times. In contrast, not all the methods are in the same development stage; thus, we suggest further investigations to develop one (or more) hurdle-like non-thermal method able to meet both food production requirements and the modern consumers' demand.
\end{abstract}

Keywords: fish; spoilage; non-thermal atmospheric plasma; pulsed electric fields; pulsed light; ultrasound; electrolyzed water

\section{Introduction}

Fish were first vertebrates to appear on Earth, more than 500 million years ago and they can be considered the oldest, simplest and most abundant living vertebrates, in terms of number of species and populations. It is estimated that there are currently about 30,000 species, of which about 24,000 are known [1].

Although there are thousands of fish species, only a small part of these has economic value and supports fishing activities. Some species are used to produce protein supplements for human and animal consumption (fishmeal) or into the preparation of food products such as margarine, cosmetics, paints or even fertilizers, but most of them are appreciated for their meats and are a consistent part of the diet of the human being.

Due to their composition, fish products play a key role in a healthy diet for different reasons [2]. First, they are rich in proteins (up to $20 \%$ of weight) with high biological value due to the presence of essential amino acids. Then, the content in unsaturated fats 
(Omega-3), mainly eicosapentaenoic acid (EPA) and docosahexaenoic acid (DHA), allow fish products to maintain good health, reduce inflammation and control blood clotting and triglyceride levels. Finally, the presence of sodium and phosphorus supports the proper functioning of the thyroid gland (regulation of basal metabolism; consequently, it is important in the prevention of obesity) and calcium needed for bone formation, such as the main vitamins present (B and D) [2].

As for other foods, the achievement of high-quality standards is the main objective of the production chain of fish products and this purpose is inextricably linked to the freshness of the raw material. According to Oehlenschläger and Sörensen [3], freshness of fish means that a fish, in its entire characteristics, is not far away from those characteristics it had in the living state, or that only a short time has passed since the fish has been caught or harvested. Physical, chemical, microbiological and biochemical transformations happen immediately after death, resulting in a progressive loss of food properties in terms of taste and quality.

The high perishability of fish products is mainly due to their peculiar composition and structure, even if storage time and temperature are crucial factors for the final quality of the product. The major cause of fish perishability is attributable to the high content in non-protein nitrogen compounds and to the low acidity $(\mathrm{pH}>6)$ of the flesh, which are conditions favourable to the growth of microorganism-producing metabolites that affect the organoleptic properties of the products. Nevertheless, the rate of spoilage is also due to the kind of fish species, the sanitary conditions on board and the amount of food in the guts [4].

Traditionally, the methods used to extend the shelf-life of fish products include fermentation, smoking, salting and marinating, or thermal treatments such as chilling, refrigeration, freezing, drying, boiling, steaming, etc. However, all these techniques are associated with undesirable changes, from a reduced nutritional value to worsened sensory attributes, which fight against the increasing demand of consumers for minimally processed foods with high quality. Thus, in recent years some alternative methods have been proposed as innovative processing technologies able to guarantee an extension of shelf-life while minimally affecting their organoleptic properties.

The present review aims to describe the primary mechanisms of some of these innovative methods applied to preserve quality and safety of fish products; namely, non-thermal atmospheric plasma (NTAP), pulsed electric fields (PEF), pulsed light (PL), ultrasounds (US) and electrolyzed water (EW) are analysed, focusing on the main results of the studies published over the last 10 years. After a description of the main mechanisms involved in fish spoilage, each innovative approach is addressed focusing on its limits and benefits, in order to provide a global overview about these promising emerging technologies and to facilitate their greater use at industrial level.

\section{Fish Spoilage}

In general, the rapid spoilage of fish after harvest is mainly due to different mechanisms, including (i) post mortem enzymic autolysis, (ii) microbial spoilage and (iii) oxidation of lipids.

Immediately after slaughter, the endogenous autolytic enzymes present in fish muscle become highly active and begin a proteolytic process which leads to protein decomposition and solubilization; peptides and free amino acids formed via autolysis, as well as biogenic amines formed through the action of decarboxylases, lead to fish spoilage [5].

Trimethylamine (TMA) is the main indicator of unpleasant 'fishy smell'; it is a volatile nitrogenous base, produced post mortem in fish by the degradation of Trimethylamine Oxide (TMAO). TMA is below the detection limit in freshly caught fish, but some bacteria, such as Shewanella putrefaciens, Aeromonas spp., Enterobacteriaceae, Photobacterium phosphoreum, Vibrio spp., Micrococcus, Acinetobacter, Moraxella, use TMAO as an osmoregulant to avoid dehydration in marine environments and tissue waterlogging in fresh water by reducing TMAO to TMA, creating the ammonia-like off-flavours [4]. 
Other biological amines (BAs) are produced through microbial decarboxylation, including histamine, putrescine, cadaverine, spermidine and spermine [6]. Among BAs, histamine is the degradation product of histidine. Some histamine is produced by endogenous tissue enzymes in relatively small quantities, immediately after fish capture, while most histamine is produced by the bacterial flora [7]. The bacteria directly involved in the production of high levels of histamine are those possessing the enzyme histidine decarboxylase, such as P. phosphoreum, Enterobacteriaceae and Pseudomonadaceae (including Morganella morganii and Klebsiella pneumoniae, Proteus and Pseudomonas spp.) [8-10].

However, it is known that changes in the organoleptic characteristics of fish depend mainly on an increase in the microbial load. In particular, two groups of microorganisms can be distinguished in fish, namely, the indigenous or autochthonous microbiota and the exogenous or allochthonous microbiota. In fish from temperate or warm waters, the autochthonous microbial flora consists mainly of narrow aerobic or facultative aerobic mesophilic Gram-negative (Pseudomonas spp., Moraxella, Acinetobacter, Flavobacterium, Xanthomonas and Vibrio) and Gram-positive bacterial species (Bacillus, Corynebacterium, Micrococcus and Lactobacillus). Whereas, in cold-water fish, it consists of Gram-negative species in the surface mucus (mainly Pseudomonas, Alteromonas, Photobacterium, and Shewanella) and Gram-positive species in the intestinal contents (Clostridium spp.) [11-13]. The exogenous microbiota consists of typically terrestrial microbial species, such as Enterococcus, Escherichia coli, Salmonella, Enterobacter, Klebsiella, Shigella and Yersinia. This type of contamination mainly affects fish living near the coast contaminated by sewage from large urban agglomerations [14].

Finally, particularly in fatty fish, chemical oxidation of lipids is a common cause of spoilage which leads to the formation of all those compounds conferring the characteristic rancid off-flavours to spoiled fatty fish. Spoilage can be also caused by lipid hydrolysis through lipolysis. Lipolytic enzymes can either be endogenous of the fish itself (present in the fish skin, blood and tissue) or can be the product of the psychrotrophic microorganism's metabolism. Regardless the origin of the enzymes, the fatty acids formed during hydrolysis interact with sarcoplasmic and myofibrillar fish proteins, causing denaturation and texture changes [15].

A summary of the main types of fish spoilage, together with the causes and the changes observed, is presented in Table 1. Even though the spoilage causes of fish can be explained through the above-mentioned processes, in general, all these mechanisms progress simultaneously, accelerating the overall spoilage of these products. 
Table 1. Types of spoilage, causes and main changes observed in spoiled fish.

\begin{tabular}{|c|c|c|}
\hline Types of Fish Spoilage & Causes & Changes \\
\hline \multicolumn{3}{|l|}{ Biological } \\
\hline Enzymatic & $\begin{array}{l}\text { Glycolytic enzymes } \\
\text { Autolytic enzymes } \\
\text { Cathepsins } \\
\text { Chymotrypsin, trypsin, } \\
\text { carboxy-peptidases } \\
\text { Calpain } \\
\text { Collagenases } \\
\text { Trimethylamine Oxide (TMAO) } \\
\text { demethylase }\end{array}$ & $\begin{array}{l}\text { Lactic acid production, } \\
\text { flavour changes in fish flesh } \\
\text { (nucleotide degradation), } \\
\text { belly-bursting, colour change } \\
\text { (black discoloration, } \\
\text { yellowing of fish flesh, } \\
\text { brown discoloration) }\end{array}$ \\
\hline$>$ Microbial & $\begin{array}{l}\text { Specific Spoilage Organisms (SSO) } \\
\text { (Pseudomonas, Shewanella, } \\
\text { Photobacterium, Acinetobacter, } \\
\text { Aeromonas, Moraxella, } \mathrm{H}_{2} \mathrm{~S} \\
\text { producing bacteria) } \\
\text { Pathogenic bacteria: } \\
\text { - Indigenous bacteria } \\
\quad \text { (Clostridium, Vibrio sp., etc.) } \\
\text { - Non-indigenous bacteria } \\
\quad \text { (Salmonella sp., Escherichia } \\
\quad \text { coli, Shigella) }\end{array}$ & $\begin{array}{l}\text { Loss of juiciness, firm texture, } \\
\text { discolouration, and formation } \\
\text { of ammonia-like off-flavours } \\
\text { due to TMA production }\end{array}$ \\
\hline \multirow[t]{2}{*}{ Chemical } & Oxidative rancidity & $\begin{array}{l}\text { Rancid flavour and odour, } \\
\text { texture changes }\end{array}$ \\
\hline & Non- enzymatic oxidation & Discolouration \\
\hline
\end{tabular}

\section{Innovative Preservation Methods Applied to Fish Products}

The purpose of an optimal preservation method should be counteracting the causes of food deterioration maintaining its chemical (its composition), physical (its condition), organoleptic (taste, smell and colour) and nutritional (presence of proteins, fats and carbohydrates, vitamins, mineral salts and water) properties.

Therefore, besides traditional preservation methods, the great challenge of modern food technology is to develop less aggressive preservation processes, which keep the product 'natural', although with a lower shelf-life.

Non-thermal technologies are able to significantly inactivate microorganisms in food, extend shelf-life without significant changes in sensory perception and maintain the nutritional value of the processed food [16]. Among the main non-thermal inactivation techniques studied to be applied for fish products, non-thermal atmospheric plasma (NTAP), pulsed electric fields (PEF), pulsed light (PL), ultrasound (US) and electrolysed water (EW) are described in the following sections, the benefits and the limits of each method are highlighted and the potential positive or negative effect on the quality of the treated products is underlined.

\subsection{Non-Thermal Atmospheric Plasma (NTAP)}

In physics and chemistry, the term plasma is used to denote the state of an ionised gas. Plasma is considered the fourth state of matter, alongside the liquid, solid and gaseous states. While the presence of plasma on Earth is relatively rare (with the exception of lightning and the aurora borealis), in the Universe, it constitutes more than $99 \%$ of known matter; the upper layers of the Earth's atmosphere (ionosphere), the outer gaseous layers of the Sun and stars and interstellar space are plasmas (natural plasmas).

A plasma can be generated artificially by supplying a gas with sufficiently high energy by means of lasers, shock waves, electric arcs, or electric and magnetic fields (glow discharge). There are two types of plasma, thermal and non-thermal atmospheric plasma 
(NTAP), depending on the conditions under which it is generated. Plasma generated at ambient pressure and temperature is called cold plasma (CP), atmospheric cold plasma (ACP), or non-thermal atmospheric plasma (NTAP) and it differs from thermal plasma obtained at higher powers and pressures. To generate NTAP, any type of energy (electrical, thermal, optical, radioactive and electromagnetic) can be used to ionise gases, but mainly electrical and electromagnetic fields are used.

Plasma has a neutral ionised gaseous form consisting of ions, free electrons, gas atoms and molecules, as well as UV photons depending on the process parameters and the gas used [17]. It is created after exposure of the gas to an electric field created between two electrodes (cathode and anode), separated by a small distance of $1 \mathrm{~cm}$. The gases mainly used for plasma generation, which can also influence its properties, are oxygen $\left(\mathrm{O}_{2}\right)$, nitrogen $\left(\mathrm{N}_{2}\right)$, carbon dioxide $\left(\mathrm{CO}_{2}\right)$ and noble gases, individually or in combination for optimum results. Oxygen seems to be more effective than the other gases due to its ability to cause greater oxidation of nucleic acids and amino acids [18].

Plasma technology has proven to be a successful tool in both the food sector (for the decontamination of abiotic food surfaces, such as packaging materials, foods in their final packaging and various food products) and medical sector $[19,20]$. In the last decade, NTAP technology has been widely used for the preservation of various food products, such as meat [21] and fresh agricultural products [22], while its use in fish and seafood is still limited [23-25].

The effectiveness of this technology obviously depends on many factors, such as voltage, frequency, treatment time, working gas composition (WGC), post-treatment/exposure time and sample surface area $[24,26]$. The type and concentration of reactive species (RESPE) produced, such as reactive nitrogen species (RNS) and reactive oxygen species (ROS), including ozone, peroxide, singlet oxygen and different types of nitrogen oxides $(\mathrm{NxOy})$, are mainly responsible for the inactivation of microorganisms and depend on the above parameters.

However, this technology is only able to inactivate microorganisms on the surface of solid food, due to its poor penetration capacity. When a food has high microbial loads that form multiple layers of bacteria on the surface, the upper layers of cells protect those below and the decontamination effect is unfortunately not complete. Three mechanisms of action have been observed for the inactivation of microorganisms: (1) the direct disruption of the membrane or cell wall, with leakage of cellular components; (2) oxidative damage to membranes or intracellular components, such as proteins and carbohydrates; (3) damage to cellular DNA.

As shown in Table 2, NTAP technology has recently been proposed to inactivate many common pathogens in fish products (Staphyloccocus aureus, Listeria monocytogenes, Salmonella Typhimurium and Enteritidis, Clostridium perfringens, E. coli), various spoilage and spoilage microorganisms (Pseudomonas, hydrogen sulphide-producing microorganisms, Enterobacteriaceae), including yeasts and fungi (Cladosporium cladosporioides and Penicillium citrinum), standing up as a precious additional tool for the successfully decontamination of various food and seafood products.

A global overview of the analysed literature shows that NTAP could be suggested to extend the shelf-life of fish products due to its beneficial effects on the inactivation of microorganisms and enzymes (Table 2).

In general, a good effectiveness of this technology for microbial decontamination was always observed, also improving the food safety of treated products; the problem of the presence of $S$. aureus, for example, was found to be completely eliminated in semi dried mackerel pike by Puligundla et al. [27], who reported an inactivation of $3.08 \log$ CFU/g by a treatment with plasma over $10 \mathrm{~min}$. Similar results were recovered by Hajhoseini et al. [28] in fish nuggets and by Choi et al. [29,30] in dried squid shreds and black mouth angler.

Regardless the procedure used to generate plasma (corona discharge plasma jet, cold oxygen plasma, high voltage plasma, etc.), the inhibition of the main specific spoilage organisms (SSOs) of fish was generally recovered; in 2019, for instance, Albertos et al. [31] 
observed significant inhibitions of the total aerobic mesophiles and psychrotrophs, lactic acid bacteria, Enterobacteriaceae and Pseudomonas spp. by applying plasma at $80 \mathrm{kV}$ for $5 \mathrm{~min}$ to herring (Clupea harengus). Similarly, plasma treatments reduced SSOs' growth in mackerel fillets [32] and Asian sea bass slices [23,24,26,33].

Some researchers reported an additive effect by using different gas compositions (air, nitrogen, oxygen, argon, etc.) at different pressures for different time intervals, singly or in combination, for plasma generation and packaging types [34], or by pre-treating with chitooligosaccharides [35]; the NTAP effects were further enhanced in terms of microbial destruction and attributed to further diversification in the generation of reactive species.

Focusing on the reduction in enzymatic activity, chemically active species generated by NTAP could cause bond cleavage and side-chain modifications of enzymes, altering their secondary structure and, subsequently, their functionality [36]. Although few studies have analysed this issue in fish products, some authors have observed that $4 \mathrm{~min}$ treatments at $60 \mathrm{kV}$ voltage decreased the proteolytic activity (50-64\%) in large head hairtail (Trichiurus lepturus) [37] and in Argentine shortfin squid (Argentinus ilex) [38], thus slowing down the degradation of myofibrillar and collagenous proteins responsible of the fish softening and texture worsening. The inhibition of polyphenol oxidase by the application of NTAP in white shrimps was also recovered [39], as well as the inhibition of lipases, proteases and other enzymes $[23,24,33,38,40,41]$. However, this aspect needs to be further investigated.

The main limitation observed in almost all case studies analysed was lipid oxidation, which increases exponentially as exposure time and energy used raise; this can lead to the creation of short-chain fatty acids, aldehydes, acid hydroxides and ketoacids, thus causing off-flavours and off-odours during storage. However, some recent investigations found that pre-treatment of fish products with natural extracts rich in antioxidants could retard the rate of lipid oxidation in samples treated with NTAP [25,26,33-35].

In general, the sensorial qualities were unaffected by the application of cold plasma, even if samples treated for a longer time showed a lowered overall acceptability and a higher lipid oxidation.

As a final consideration, this technology has demonstrated an excellent ability to inactivate microorganisms without promoting their resistance or triggering deteriorative processes. Its application as a minimal processing method to preserve the quality of fish products is recommendable, since it offers very important advantages for food industries, namely, (1) it allows short processing times; (2) it is effective at low temperatures; (3) it is non-toxic; (4) its application reduces the consumption of water and chemical agents (less effluents).

Unfortunately, this method is not currently allowed to be used on foods as a great research effort is still necessary to accomplish its successful implementation at industrial level as a safe and effective alternative to traditional preservation methods. In fact, the difficulty in interpreting the data obtained by different studies using very diverse equipment and operating conditions, resulting in very different plasmas in terms of properties and, consequently, with very different antimicrobial effectiveness, hinders its application in the food industry. 
Table 2. Application of non-thermal atmospheric plasma (NTAP) technology to fish products; main results and limitations of the technology considered.

\begin{tabular}{|c|c|c|c|c|c|}
\hline Fish Product & Treatment Conditions & Tested Microorganisms & Results & Limit & Reference \\
\hline $\begin{array}{l}\text { Dried filefish fillets } \\
\text { (Stephanolepis cirrhifer) }\end{array}$ & $\begin{array}{l}\text { Cold oxygen plasma (COP); } \\
\text { treatment time, 3-20 min. }\end{array}$ & $\begin{array}{l}\text { Cladosporium cladosporioides } \\
\text { Penicillium citrinum }\end{array}$ & $\begin{array}{l}\text { Reduction }>1 \log _{10} \mathrm{CFU} / \mathrm{g} \text { was } \\
\text { observed in the fillets treated with } \\
\text { COP for }>10 \mathrm{~min} \text {. }\end{array}$ & $\begin{array}{l}\text { Exposure to } 20 \text { min of treatment } \\
\text { showed an increase in lipid } \\
\text { peroxidation and a decrease in } \\
\text { overall sensory acceptance. }\end{array}$ & [18] \\
\hline Dried squid shreds & $\begin{array}{l}\text { The corona discharge plasma } \\
\text { jet (CDPJ) was generated } \\
\text { using } 220 \mathrm{~V} \text { AC power with } \\
\text { an output voltage of } 20 \mathrm{kV} \\
\text { DC, at a current of } 1.50 \mathrm{~A} \text { and } \\
\text { a frequency of } 58 \mathrm{kHz} \text {. }\end{array}$ & $\begin{array}{l}\text { Total aerobic count } \\
\text { Marine bacteria } \\
\text { Staphylococcus aureus }\end{array}$ & $\begin{array}{l}\text { Aerobic bacteria, marine bacteria and } \\
\text { St. aureus were inactivated by } 2.0,1.6 \\
\text { and } 0.9 \text { log units, respectively. } \\
\text { Additionally, a } 0.9 \text { log reduction in } \\
\text { yeasts and mould contaminants } \\
\text { was observed. }\end{array}$ & $\begin{array}{l}\text { A change in moisture content and } \\
\text { thiobarbituric acid concentration } \\
\text { was observed. All other } \\
\text { physico-chemical and sensory } \\
\text { properties tested were unaffected. }\end{array}$ & [29] \\
\hline $\begin{array}{l}\text { Fresh mackerel fillets } \\
\text { (Scomber scombrus) }\end{array}$ & $\begin{array}{l}\text { Plasma was generated using } \\
\text { voltages of } 70 \text { and } 80 \mathrm{kV} \text { for } \\
\text { different treatment times }(1,3 \\
\text { and } 5 \mathrm{~min}) .\end{array}$ & $\begin{array}{l}\text { Total aerobic count } \\
\text { Psychrotrophic bacteria } \\
\text { Pseudomonas spp. } \\
\text { Lactic acid bacteria }\end{array}$ & $\begin{array}{l}\text { There was no significant }(p>0.05) \\
\text { reduction in the total aerobic } \\
\text { mesophilic count, whereas } \\
\text { psychrotrophic bacteria, LAB and } \\
\text { Pseudomonas counts were } \\
\text { significantly ( } p<0.05) \text { reduced due } \\
\text { to DBD. }\end{array}$ & $\begin{array}{l}\text { Changes in immobilised and } \\
\text { extra-myofibrillar water were } \\
\text { observed. Mackerel was more } \\
\text { susceptible to lipid oxidation. } \\
\text { There was no negative influence on } \\
\text { physico-chemical parameters such } \\
\text { as pH and colour. }\end{array}$ & [42] \\
\hline
\end{tabular}


Table 2. Cont.

\section{Fish Product}

Smoked salmon

$$
1 \mathrm{kHz} \text { were used, at }
$$
high-voltage plasma jet predetermined time intervals

$(0,1,2$ and $4 \mathrm{~min})$, with intensities of up to $500 \mathrm{~mJ} / \mathrm{cm}^{2}$.

\section{Tested Microorganisms}

Listeria monocytogenes

Listeria innocua

Salmonella Typhimurium

Salmonella Enteritidis

$$
\text { St. aureus }
$$

Escherichia coli $\mathrm{O} 157: \mathrm{H} 7$

Aeromonas hydrophila

Plesiomonas shigelloides
Asian sea bass slices

Plasma was generated using

a voltage of $80 \mathrm{kV}$ for $0,2,5$,

7.5 and $10 \mathrm{~min}$ at room

temperature $\left(28 \pm 2{ }^{\circ} \mathrm{C}\right)$.
Total viable count

Psychrophilic bacteria

$\mathrm{H}_{2} \mathrm{~S}$-producing bacteria

Enterobacteriaceae

Pseudomonas

Clostridium perfringens

Lactic acid bacteria
An additive lethal effect of the two techniques was found, with a

reduction of $0.5-1.3 \log \mathrm{CFU} / \mathrm{g}$ in the microbial population

exposure times have caused

significant changes in the

Reference

\section{In treated samples, total viable count}

(TVC) was lower than the acceptable

limit ( $\log 10^{6} \mathrm{CFU} / \mathrm{g}$ sample) within

18 days. The growth of various

pathogenic and spoilage bacteria,

including psychrophilic bacteria, $\mathrm{Cl}$. perfringens (not detected), lactic acid

bacteria (3.77-4.37 log CFU/g)

Enterobacteriaceae (4.03-4.50 log

CFU/g), Pseudomonas (6.62-6.82 log $\mathrm{CFU} / \mathrm{g}$ ) and hydrogen sulphide

$\left(\mathrm{H}_{2} \mathrm{~S}\right)$-producing (4.04-5.05 log

$\mathrm{CFU} / \mathrm{g}$ ) bacteria, of treated slices was lower than control samples. A 5-min treatment extended shelf-life to 12 days against 6 days recovered for samples without this treatment.

Total viable count

Plasma was generated with

Refrigerated Asian Sea bass slices an input voltage of $230 \mathrm{~V}$ at

$50 \mathrm{~Hz}$ and an output voltage

controlled within 0-120 kV. sychrophilic bacteri Lactic acid bacteria

Pseudomonas spp.

$\mathrm{H}_{2} \mathrm{~S}$-producing bacteria Enterobacteriaceae
The shelf-life was extended to

15 days, while the control (kept in air) had shelf-life of 6 days
Pronounced lipid oxidation was observed in the 7.5 and $10 \mathrm{~min}$

treatments. There was also a

reduction in the amount of PUFA

and MUFA fatty acids by $28-64 \%$

and $40-46 \%$, immediately after

treatment and after 12 days of storage. 
Table 2. Cont

\begin{tabular}{|c|c|c|c|c|c|}
\hline Fish Product & Treatment Conditions & Tested Microorganisms & Results & Limit & Reference \\
\hline $\begin{array}{l}\text { Asian sea bass slices } \\
\text { (Lates calcarifer) }\end{array}$ & $\begin{array}{l}\text { Cold atmospheric plasma } \\
\text { was generated with a mixture } \\
\text { of argon and oxygen }(90 \% \\
\text { Ar } / 10 \% \mathrm{O} 2) \text { for } 5 \text { min and } \\
\text { used in combination with } \\
\text { chito-oligosaccharides (COS) } \\
\text { at different concentrations } \\
(0.05,0.1 \text { and } 0.2 \mathrm{~g} / 100 \mathrm{~g}) .\end{array}$ & $\begin{array}{l}\text { Total Viable Count } \\
\text { Psychrophilic bacteria } \\
\text { Enterobacteriaceae } \\
\text { Pseudomonas spp. } \\
\mathrm{H}_{2} \text { S-producing bacteria } \\
\text { Lactic acid bacteria } \\
\text { Cl. perfringens }\end{array}$ & $\begin{array}{c}\text { Reduction in L. monocytogenes, } \\
\text { between } 1.21 \text { and } 1.52 \log \text { CFU/g; } \\
\text { reduction in } S \text {. Typhimurium, } \\
\text { between } 1.44 \text { and } 1.75 \log \text { CFU/g. } \\
\text { The thiobarbituric acid reactive } \\
\text { substances (TBARS) and peroxide } \\
\text { values (PV) of treated samples were } \\
\text { reduced. Sensory acceptability } \\
\text { was improved. }\end{array}$ & No negative effects were found. & {$[34]$} \\
\hline $\begin{array}{c}\text { Grass carp } \\
\text { (Ctenopharyngodon Idella) }\end{array}$ & $\begin{array}{l}\text { Plasma was generated using } \\
\text { air as the feed gas, at a } \\
\text { current and frequency of } \\
1.05 \mathrm{~A} \text { and } 10 \mathrm{kHz} \text {, } \\
\text { respectively, under } \\
\text { atmospheric pressure and an } \\
\text { ambient temperature of } 25^{\circ} \mathrm{C} \text {. } \\
\text { The applied voltage was } 70 \mathrm{~V} \\
\text { with a peak input power of } \\
73.5 \mathrm{~W} .\end{array}$ & $\begin{array}{l}\text { L. monocytogenes } \\
\text { S. Typhimurium }\end{array}$ & $\begin{array}{l}\text { Logarithmic reductions were } \\
\text { observed between } 1.21 \text { and } 1.52 \text { for } L \text {. } \\
\text { monocytogenes and between } 1.44 \text { and } \\
1.75 \text { for } S \text {. Typhimurium. }\end{array}$ & $\begin{array}{l}\text { Reduction in } \mathrm{pH} \text { and increase in } \\
\text { total acidity level in samples and } \\
\text { change in colour. }\end{array}$ & [45] \\
\hline
\end{tabular}




\subsection{Pulsed Electric Fields (PEF)}

PEF is an emerging technology that involves the delivery of short high-power electrical pulses (microsecond) to a product placed in a treatment chamber, confined between electrodes. The process produces modest thermal increases without causing any effect in the product. The application of an external electric field to biological cells (animal, plant or microbial) causes damage to the cell membrane. To date, a number of theoretical models have been suggested, but there is still no clear evidence of the mechanism of action at the cellular level. The most accepted theory is the electromechanical model introduced by Zimmermann et al. [46], which considers the cell membrane to be a capacitor with a low dielectric constant. Free charges of opposite polarity are present on both sides of a membrane (inner and outer), resulting in a natural transmembrane potential. Exposure to an electric field induces accumulation of charges inside and outside the cell across the membrane and thus an increase in transmembrane potential.

When the transmembrane potential exceeds a critical value, there is a rapid electrical collapse of the cell membrane, whose structure changes, with an increase in permeability, loss of cellular components and collapse of the proton motive force. Charges with opposite signs are formed on both sides of the membrane, compressing it and forming pores. The breaking of the membrane can be reversible or irreversible, depending on the intensity of the treatment [47]. When the induced pores are small compared to the area of the membrane and are generated with a low intensity PEF treatment, the effect is reversible [48]. Based on this phenomenon, electroporation (permeabilization of the cell membrane caused by an external electric field) has been studied in practical applications on various biological systems in the fields of medicine, biology and food processing.

Besides being a non-thermal alternative, this technique proved to have a good impact on the microstructure of muscle foods [49,50], without affecting physical, organoleptic and functional characteristics [51,52]. For example, Gudmundsson and Hafsteinsson [53] observed that salmon fillets improved significantly their texture and microstructure when subjected to a mild PEF treatment $(<2 \mathrm{kV} / \mathrm{cm}, 20-40$ pulses). Contrarily, no positive effects were observed on the tenderness of some types of mussels and molluscs [54].

Although the technique was known 50 years ago, PEF can be still considered an emerging technology, because its industrial applications are recent. Initially, the use of PEF in food processing has attracted great interest especially as a method to improve the extraction of specific components or improve drying efficiency $[55,56]$. The technology is, in fact, well suited for the extraction of high-value compounds from fish by-products, as it destroys only the biological cells in the food matrix with a high extraction efficiency, also compared to other methods [57]. Surprising results were recovered by using PEF to extract proteins from mussels [58], calcium and chondroitin sulphate from fishbones [57,59] and proteins from abalone viscera [60].

However, more recently, the use of PEF has been suggested also as a novel preservation method, due to its capacity to rapidly inactivate microorganisms, producing foods with great nutritional and sensory quality [61-63]. It has been also shown that using PEF in combination with other non-thermal technologies such as UV irradiation, microwaves, high-intensity light pulses (HILP) and high hydrostatic pressure (HHP) increased microbial inactivation [64,65].

From the few papers available in the literature, PEF appear to have no negative effects on sensory and nutritional qualities when applied to fish products, although this aspect merits further investigation. In contrast to NTAP (which is mainly used on solid foods), PEF technology is preferred for treating liquid foods; this explains the limited number of studies on fish and seafood. In 2020, Shiekh et al. [25] tested the effect of pulsed electric fields on microbiological changes in Pacific white shrimp (Litopenaeus vannamei). The samples were stored at $4{ }^{\circ} \mathrm{C}$ for 10 days and were treated every second day with PEF at different densities. The treatment conditions were PEF-T1 $(5 \mathrm{kV} / \mathrm{cm}, 200$ pulses), PEF-T2 $(10 \mathrm{kV} / \mathrm{cm}$, 400 pulses) and PEF-T3 (15 kV/cm, 600 pulses) with the PEF specific energy of 54,214 and 
$483 \mathrm{~kJ} / \mathrm{kg}$, respectively. The most effective treatment for bacterial inactivation was the highintensity treatment (PEF-T3), which resulted in a low microbial load until the end of storage (approximately $4.58 \log$ CFU/g). The technology appeared as an effective method to inhibit psychrophilic bacteria, which are the main cause of shrimp spoilage during cold storage. In addition to the microbiological result, chemical inhibition of the enzyme polyphenol oxidase was observed, resulting in improved sensory and nutritional properties.

The limitation to its wider use in the food industry lies in the high initial cost of the equipment, as well as the fact that studies on its application to food products have mainly been conducted on liquids with low electrical conductivity. Although PEF is a non-thermal treatment, when used at high intensity, there is a significant increase in temperature, which must be considered with sensitive compounds such as proteins $[61,66]$. Further investigations should be performed to evaluate the impact of this technology on the quality parameters of fish products (e.g., tenderness, colour, oxidation, weight loss and water retention capacity). Moreover, the inefficiency of this technique against the reduction in natural enzymes present in fish is another shortcoming of this emerging technology [67].

Nevertheless, the transfer of PEF technology to the fish industry would be highly favourable due to the low energy consumption and short processing times required.

\subsection{Pulsed Light (PL)}

Pulsed light (PL) is a non-thermal technology, approved by the FDA (Food and Drug Administration), which involves the emission of short flashes of light in a broad spectrum [68]. PL technology was first used in the medical field to sterilise medical devices and then in water purification processes; recently, it has also found new applications in air sanitation. In 1996, the FDA approved the use of PL technology for food production, processing and handling processes [69]. It is recommended to use the xenon lamp with surface emission of wavelengths between 200 and $1100 \mathrm{~nm}$, with a cumulative treatment not exceeding $12 \mathrm{~J} / \mathrm{cm}^{2}$ and a pulse width not exceeding $2 \mathrm{~ms}$. In the food industry, pulsed light technology is mainly used for ready-to-eat products, meat and fish products, or dairy products, which are subject to rapid spoilage and require delicate preservation measures. The decontamination effect of PL treatments is mainly due to the photochemical changes caused by UV-C radiation on microbial DNA, in combination with the photothermal and photophysical damage caused to cells by water vaporisation and membrane destruction [70]. The effectiveness of this method has been recognised against Gram-positive and -negative bacteria, as well as fungal spores, and the lethal effect is greater than UV treatment applied in continuous. In particular, it has been shown that Gram-positive bacteria are more resistant than Gram-negative bacteria and fungal spores show higher resistance than bacteria [71], although Gómez-López et al. [72] reported opposite results. However, each microorganism has a different sensitivity to treatment and this may be related to differences in the composition of the bacterial cell wall and their protective and repair mechanisms against damage [71]. The potential of pulsed light treatment depends on many factors, such as the exposure time, variations in the power of the UV source (which affects the electromagnetic wavelength), the presence of particles that can protect microorganisms from UV and the ability of the microorganisms to resist the radiation during exposure. High power, long treatment time and the closer distance between target and flash lamp cause an increase in microbial reduction but a consequent loss of quality, so it is necessary to find the optimal treatment conditions to improve microbiological safety without affecting food quality $[73,74]$. For example, in a study performed on salmon fillets, the application of PL at $5.6 \mathrm{~J} / \mathrm{cm}^{2}$ at intervals of 3 and $5 \mathrm{~cm}$ for $60 \mathrm{~s}$, caused an increase in the product's temperature up to $100{ }^{\circ} \mathrm{C}$, resulting in good microbial reduction but significant changes in colour and quality. However, the same treating time (60 s) applied at a longer distance $(8 \mathrm{~cm})$, was able to reduce E. coli O157:H7 and L. monocytogenes by approximately $1 \mathrm{log}$ $\mathrm{CFU} / \mathrm{g}$, without compromising the quality of the fish product [75].

According to the study by Mandal et al. [70], PL technology is an effective, fast and mild decontamination method and its applications are increasing not only for food 
contact surfaces, but also for the decontamination of packaging materials. However, this technology, due to the non-uniform shape and opacity of the products, cannot be used for sterilisation processes, but only for reducing the microbial load. In addition, the application of PL is particularly difficult in the case of foods in granular form, such as cereals or spices, due to the shadow effect of the surfaces, which does not allow light to reach the microorganisms.

As reported in Table 3, PL has been recently suggested to be used in fish products for the inactivation of altering bacteria (P. phosphoreum, Serratia liquefaciens, S. putrefaciens, Brochothrix thermosphacta, Pseudomonas group I and Pseudomonas groups III and IV) and L. monocytogenes, which has proven to be more resistant. A careful review of the literature also highlighted a possible use of PL technology for the decontamination of packaged fish products, e.g., in vacuum packs, where the product surface is completely or almost completely exposed to the pulsed light. Unfortunately, the use of this technique resulted in a short-term decline in sensory quality. To maintain the attributes of the product, lower fluences should be applied, but this would cause lower inactivation of pathogens. Moreover, PL used alone could (1) induce surface discoloration, (2) accelerate product senescence and oxidative processes, (3) increase lipid oxidation as hydrogen peroxide and superoxide radicals are formed indirectly by UV light and (4) have an impact on colour (since the peroxide formed during prolonged treatment can diminish pigments) and on protein fragmentation with an impact on texture.

Therefore, further research is needed to overcome these limitations and to analyse other aspects, such as the ability of PL to increase the nutritional attributes of products, leading to new opportunities for its use as a biofortification technology.

\subsection{Ultrasound (US)}

Ultrasound is one of the innovative non-thermal techniques that is proving to be very successful in the food sector where it is actually used for freezing, cutting, drying, homogenisation, degassing, foaming, filtration and extraction processes. More recently, it has been also proposed as an alternative to heat treatments to control microbial growth [76-79]. Ultrasonic waves used in the food industry are low energy, high frequency $(16-100 \mathrm{kHz})$ waves. Any type of system used for US production consists of three parts: (1) a current generator that supplies electricity at the desired frequency to the transducer; (2) a transducer or converter, which converts electrical energy into mechanical vibrations (pressure waves) that are conveyed into a probe; (3) a probe that amplifies the vibration produced forming the sonication site that can be continuous or discontinuous. Typical ultrasonic systems are the ultrasonic bath, ultrasonic probes, parallel vibrating plates and radial vibrating systems. The mechanism behind sonication is the well-known phenomenon of cavitation, i.e., the repeated creation of microbubbles inside a liquid, followed by their implosion. The pressure resulting from these implosions causes the main bactericidal effect of ultrasound, which consists of a thinning of cell membranes, localised heating and production of free radicals [76-79]. The effectiveness of the treatment depends on several factors, such as type of microorganism treated, amplitude of the ultrasonic waves, exposure/contact time, volume and composition of the food to be treated and temperature of the treatment. The literature reports that Gram-positive cells are more resistant to ultrasound than Gram-negative cells and this may be due to the structure of the cell wall. In addition, vegetative cells are more susceptible to bacterial spores. To make the action of ultrasound on microorganisms more effective, sonication is often combined with other treatments. It is common to use mild heat treatments (thermo-sonics), high pressures (mano-sonics), or both (mano-thermo-sonics) [80].

Ojiha et al. [81] proposed a unifying mechanism to address the effect of US on cells; this mechanism is known as sonoporation and relies upon six different ways of acting on cells: push, pull, acoustic streaming, jetting, translation and cavitation; the combination of these mechanisms causes the disturbance of microbial homeostasis, morphological changes and the disruption of both cell wall and cell membrane. 
US has been used for microbial inactivation in a wide variety of media, but only a few studies have focused on fish products (Table 3). In general, the ultrasonic waves used in fish studies are high-energy, low-frequency waves of $20-100 \mathrm{kHz}$. In a recent investigation conducted by Mikš-Krajnik et al. [82], US was used to decontaminate salmon fillets (L. monocytogenes, total bacterial count, yeast and moulds). The results showed different effects for each microorganism; L. monocytogenes and coliforms were reduced by 0.4 and $0.3 \log \mathrm{CFU} / \mathrm{g}$, respectively, while there was no significant reduction in total bacterial count, yeasts and moulds. The presence of irregularities on the surface of the fish fillet was speculated as the cause of these differences. With regard to quality indicators, an increased moisture content and a slight colour change were observed.

When applied as a single-use technology, this technology cannot achieve the $5 \log$ reduction in compliance with the FDA (2004) requirements [69]; thus, its use is actually suggested to be combined with mild thermal treatments. The treatment appears better than traditional pasteurisation techniques, due to the absence of negative effects on the nutrient content and physical characteristics of treated food products. However, the effect of the application time should be considered; longer exposure times (more than $60 \mathrm{~min}$ ) are not recommended. Contrarily, when this technology is applied for short times (about $20 \mathrm{~min}$ ), it improves the texture and does not affect the physico-chemical characteristics [83].

Similar to PEF, US is proposed to be industrially used as a method of extracting compounds from plant and animal tissues; for instance, the cavitation effect generated by US has been exploited to extract lipids and carotenoids from crustacean processing by-products [84,85]. More, the use of US is suggested in the fish industry to decontaminate knives used in cutting operations. This can be seen as a comprehensive approach to improve the quality of fish products [86].

Evaluating the results of recent studies, US can be seen as an interesting technology to improve the stability of fish products. The combination with other technologies, such as PL or EW, could be an added value to further studies and to create new opportunities to implement this technology at industrial level, also considering that the method is fast, reliable, relatively cheap and easy to use.

\subsection{Electrolysed Water (EW)}

Among the relatively new proposals, electrolytic water (EW) is attracting interest as a non-thermal technique in the food industry and agriculture. Similar to all the innovative methods mentioned above, EW is safer and more effective than traditional chemical agents, to which microorganisms are becoming increasingly resistant. In fact, it is considered as a new non-thermal and environmentally friendly sanitiser.

EW was initially developed in Japan [87] and has been recognised as having a strong bactericidal effect on the main food pathogens; it is generated by a process of controlled diaphragm electrolysis produced by passing a salt solution through an electrolytic cell, where the anode and cathode are separated by a membrane. During the electrolytic process, $\mathrm{NaCl}$ splits into metallic sodium $(\mathrm{Na})$ and chlorine gas $\left(\mathrm{Cl}_{2}\right)$, while water $\left(\mathrm{H}_{2} \mathrm{O}\right)$ splits by electrolysis into hydrogen $\left(\mathrm{H}_{2}\right)$ and oxygen $\left(\mathrm{O}_{2}\right)$. The negatively charged ions $\mathrm{Cl}-$ and $\mathrm{OH}$ - lose their electrons through the generator anode, while, during this oxidation, hypochlorous acid $(\mathrm{HClO})$, hypochlorite ion $\left(\mathrm{ClO}^{-}\right)$, hydrochloric acid $(\mathrm{HCl})$, gaseous oxygen $\left(\mathrm{O}_{2}\right)$ and gaseous chlorine $\left(\mathrm{Cl}_{2}\right)$ are generated. Conversely, positively charged ions $\left(\mathrm{Na}^{+}\right.$and $\left.\mathrm{H}^{+}\right)$gain electrons pushed out of the cathode, where reduction occurs, resulting in the generation of sodium hydroxide $(\mathrm{NaOH})$ and hydrogen gas $\left(\mathrm{H}_{2}\right)$ [88]. Within the chamber, two types of EW are produced, namely, at the anode, acidic electrolysed water (AEW) or electrolytic oxidising water (EOW), with a $\mathrm{pH}$ value of $2-3$, oxidation-reduction potential (ORP) $>1100 \mathrm{mV}$ and chlorine concentration of 10 to $90 \mathrm{ppm}$, while, at the cathode, basic electrolytic oxidising water (BEW), with a $\mathrm{pH}$ value between 10 and 13 and an oxidation-reduction potential of $800-900 \mathrm{mV}$. Another type of EW is neutral electrolysed water (NEW), with a $\mathrm{pH}$ value of 7-8 and an ORP of 750-900 $\mathrm{mV}$. The effectiveness of the 
EW generated varies depending on the type and concentration of the solution, the voltage and current value, the water flow and the electrolysis time.

The antimicrobial activity of EW has been widely demonstrated against various foodborne microorganisms, such as Pseudomonas aeruginosa [89,90], S. aureus [90], E. coli O157: H7 [91], S. Typhimurium [92], L. monocytogenes [91,93], C. jejuni [93] and V. parahaemolyticus [94]. It is also effective against spores, fungi and viruses present in food, environment and food processing plants. The antimicrobial activity and mechanism of action of EW against bacteria are not yet fully described. However, it is known that chlorine and reactive oxygen can break down the microbial cell membrane and cause oxidative DNA damage.

EW has various applications in the food industry; one of the most significant is in the seafood industry, although limited effectiveness in decreasing the bacterial load on seafood at room temperature has been demonstrated. The treatment of fish products with various types of EW highlights great results for microbiological quality, but also good results in inhibiting $\mathrm{pH}$ changes, formation of total volatile basic nitrogen (TVB-N) and activity of the enzyme polyphenol oxidase (PPO) (see Table 4). Significant reductions in L. monocytogenes were observed both in salmon fillets and in carp skin after a treatment with AEW for $15 \mathrm{~min}$ [95]. Similarly, the effect of AEW was found to be very effective for reducing V. parahaemolyticus and E. coli O157:H7 on tilapia skin [96]. Although the application of EW on fish products appears a promising technique for reducing the total count of pathogenic and spoilage bacteria, at the same time, it has shown some undesirable effects on the organoleptic quality and nutritional value of food [97-100]. Since food safety must be accompanied by sensory quality, to overcome these limitations, a combination of two or more preservative and sanitizing technologies in low quantities is suggested. Consequently, several studies in the literature report the combined use of EW with MAP packaging, chitosan, or natural antimicrobial solutions [101-104]. The combined treatments compared with individual treatments showed a better preservative or even synergistic bactericidal effect, thus suggesting that the food industry would greatly benefit by adopting treatment procedures involving combinations of EW and other treatments.

However, limitations such as corrosion to equipment and detrimental effects on the quality of the treated food products, environment and human health have to be considered [105]. In addition, the high concentration of $\mathrm{NaCl}$ used for the production of acidic electrolytic water may lead to an increase in salinity in the pre-treated seafood. This can be perceived by consumers, thus lowering sensory acceptability. Finally, the chlorine ion can interact with other main components of food, thus influencing the texture of food and inducing certain reactions that occur during processing [106].

EW is successfully used in Russia and Japan as substitute of chemicals, whereas it is slowly obtaining acceptance in the US and other countries [106]. In the European Union (EU), EW can only be applied to "drinking water" and its use on food products such as fish is not yet permitted. In the near future, it is desirable that most of the industry start using EW, since these solutions are relatively simple in composition and not toxic [106]. Through further research, an advanced and dynamic EW production system able to reduce all the current limitations could be developed, also including processing settings providing the application in HACCP and sanitation SOP systems. 
Table 3. Application of pulsed light (PL) and ultrasound (US) technology to fish products; main results and limitations of the technologies considered.

\begin{tabular}{|c|c|c|c|c|c|}
\hline \multicolumn{6}{|c|}{ Pulsed Light (PL) } \\
\hline Fish Product & Treatment Conditions & Tested Microorganisms & Results & Limit & Reference \\
\hline Beef and tuna carpaccio & $\begin{array}{l}\text { A pulsed light device } \\
\text { equipped with two xenon } \\
\text { lamps was used. The lamps } \\
\text { emitted flashes of } 150 \mathrm{~J} \text {, } \\
\text { equivalent to a fluence of } \\
0.175 \mathrm{~J} / \mathrm{cm}^{2} \text { per pulse. The } \\
\text { pulse period was } 250 \mu \mathrm{\mu} \text { and } \\
\text { also the spectral output of the } \\
\text { lamp corresponded to } 30 \% \\
\text { UV light (12\% UV-C, } 10 \% \\
\text { UV-B and } 8 \% \text { UV-A), } 30 \% \\
\text { infrared radiation and } 40 \% \\
\text { visible light. }\end{array}$ & $\begin{array}{l}\text { Listeria monocytogenes } \\
\text { Escherichia coli } \\
\text { Salmonella Typhimurium } \\
\text { Vibrio parahaemolyticus }\end{array}$ & $\begin{array}{l}\text { The application of pulsed light at the } \\
\text { highest fluences tested }(8.4 \text { and } \\
\left.11.9 \mathrm{~J} / \mathrm{cm}^{2}\right) \text { improved the } \\
\text { microbiological safety of the product. } \\
\text { Reductions from } 2 \text { to } 6 \text { log } \mathrm{cfu} / \mathrm{cm}^{2} \\
\text { were achieved. }\end{array}$ & $\begin{array}{l}\text { The application of pulsed light at the } \\
\text { highest fluences tested compromised } \\
\text { the sensory quality in the short term. } \\
\text { To maintain product attributes, lower } \\
\text { fluences should be applied, albeit at } \\
\text { the expense of less inactivation of the } \\
\text { tested pathogens. }\end{array}$ & [107] \\
\hline $\begin{array}{l}\text { Refrigerated tilapia } \\
\text { (Oreochromis niloticus) } \\
\text { fillets }\end{array}$ & $\begin{array}{l}\text { After active packing with } \mathrm{O}_{2} \text {, } \\
\text { the fillets were subjected to } \\
\mathrm{UV}-\mathrm{C} \text { radiation in an } \\
\text { apparatus containing six } \\
30 \mathrm{~W} \text { and six } 55 \mathrm{~W} \text { lamps. } \\
\text { Exposure times were } \\
\text { measured every } 5 \mathrm{~s} \text { up to } \\
\text { doses of } 0.102 \pm 0.001 \mathrm{~J} / \mathrm{cm}^{2} \\
\text { and } 0.301 \pm 0.001 \mathrm{~J} / \mathrm{cm}^{2} \text {. }\end{array}$ & $\begin{array}{l}\text { Enterobacteriaceae } \\
\text { Total aerobic count }\end{array}$ & $\begin{array}{l}\text { The } \mathrm{O}_{2} \text { scavenger, UV-C doses }(0.102 \\
\left.\text { and } 0.301 \mathrm{~J} / \mathrm{cm}^{2}\right) \text { and combinations } \\
\text { of these preservation methods } \\
\text { retarded bacterial growth and the } \\
\text { formation of TVB-N and ammonia, } \\
\text { increasing the shelf-life of chilled } \\
\text { tilapia fillets to } 14-16 \text { days against } \\
9 \text { days recovered in } \\
\text { untreated samples. }\end{array}$ & $\begin{array}{l}\text { UV-C used alone induced negative } \\
\text { changes in colour, texture and } \\
\text { oxidative processes. The } \mathrm{O}_{2} \\
\text { scavenger has proven to be an } \\
\text { effective and simple alternative to } \\
\text { reduce the negative effects of } \\
\text { UV radiation. }\end{array}$ & [108] \\
\hline
\end{tabular}


Table 3. Cont.

\begin{tabular}{|c|c|c|c|c|c|}
\hline \multicolumn{6}{|c|}{ Ultrasound (US) } \\
\hline Fish Product & Treatment Conditions & Tested Microorganisms & Results & Limit & Reference \\
\hline $\begin{array}{l}\text { Refrigerated carp } \\
\text { (Ctenopharyngodon } \\
\text { idellus) fillets }\end{array}$ & $\begin{array}{l}\text { Carp fillets were treated with } \\
\text { chito-oligosaccharides }(1 \%) \\
\text { and treated with ultrasound } \\
\text { at } 40 \mathrm{kHz} \text { for } 10 \mathrm{~min} .\end{array}$ & $\begin{array}{l}\text { Aeromonas } \\
\text { Shewanella }\end{array}$ & $\begin{array}{l}\text { In comparison with control, } \\
\text { treatments had positive effect on } \\
\text { reducing the accumulation of TVB-N, } \\
\text { off-taste nucleotides and biogenic } \\
\text { amines, inhibiting microbial growth } \\
\text { and maintaining sensory quality of } \\
\text { fillets. The shelf-life of treated fillets } \\
\text { was extended by nearly } 2 \text { days when } \\
\text { compared to untreated samples. }\end{array}$ & No negative effects were observed. & [109] \\
\hline Thawed cod fillets & $\begin{array}{l}\text { The treatment was carried } \\
\text { out in an ultrasound bath } \\
\text { using three different powers, } \\
29.4 \mathrm{~W} / \mathrm{kg}(100 \%), 14.7 \mathrm{~W} / \mathrm{kg} \\
(50 \%) \text { and } 2.9 \mathrm{~W} / \mathrm{kg}(10 \%) \text {, } \\
\text { for } 20 \mathrm{~min} .\end{array}$ & $\begin{array}{c}\text { Total aerobic count } \\
\text { Mesophilic bacteria } \\
\text { Seafood spoilage organisms } \\
\text { (SSOs) } \\
\text { Enterobacteriaceae } \\
\text { Proteolytic bacteria }\end{array}$ & $\begin{array}{l}\text { The US-assisted hydration process } \\
\text { was able to control microbial growth } \\
\text { without compromising the sensory } \\
\text { quality properties of the cod fillets. }\end{array}$ & No negative effects were observed. & [110] \\
\hline $\begin{array}{l}\text { Salmon (S. salar), } \\
\text { mackerel (S. scombrus), } \\
\text { cod (G. morhua) and } \\
\text { hake (M. merluccius) }\end{array}$ & $\begin{array}{c}\text { A low-frequency }(30 \mathrm{kHz}) \\
\text { ultrasonic bath and a } \\
\text { transferred ultrasonic power } \\
\text { of } 51.41 \mathrm{~W} / 1 \text { at } 14{ }^{\circ} \mathrm{C} \\
\text { was used. }\end{array}$ & $\begin{array}{l}\text { Total mesophil and } \\
\text { psychrophil counts } \\
\text { Pseudomonas spp., } \\
\text { Enterobacteriaceae }\end{array}$ & $\begin{array}{l}\text { US treatment was able to } \\
\text { significantly reduce microbiological } \\
\text { counts in oily fish species with } \\
\text { reductions of up to } 1.5 \text { and } 1.1 \mathrm{log} \\
\text { CFU / g for psychrophilic and } \\
\text { mesophilic viable counts observed in } \\
\text { salmon and mackerel, respectively. } \\
\text { Lower reductions were observed in } \\
\text { white fish species. } \\
\text { Lipid content did not change, } \\
\text { whereas significant reductions in } \\
\text { TBARS values were observed in } \\
\text { salmon. Moisture levels increased } \\
\text { by } 8 \% \text {. }\end{array}$ & $\begin{array}{l}\text { Colour changes in salmon samples } \\
\text { were observed. }\end{array}$ & [111] \\
\hline
\end{tabular}


Table 4. Application of electrolyzed water (EW) technology to fish products; main results and limitations of the technology considered.

Fish Product

Live clam (Venerupis
philippinarum), mussel
(Mytilus edulis)

(Mytilus edulis)

\begin{tabular}{|c|c|c|}
\hline Atlantic Salmon (Salmo salar) & $\begin{array}{c}\text { Acidic electrolysed water with } \mathrm{pH} 2.7 \text {, } \\
\text { oxidation-reduction potential } 1150 \mathrm{mV} \\
\text { and free chlorine concentration of } 60 \mathrm{ppm} \\
\text { (generated at } 9-12 \mathrm{~V} \text { direct current for } \\
15 \mathrm{~min} \text { ). Neutral electrolyzed water } \\
\text { (NEW) with active hypochlorous acid } \\
(275 \mathrm{ppm} \text { ) was electrochemically } \\
\text { generated and diluted to obtain a solution } \\
\text { with an available free chlorine content of } \\
60 \mathrm{ppm} \text {, a pH of } 6.8 \text { and a potential of } \\
786 \mathrm{mV} \text {. }\end{array}$ & L. monocytogenes \\
\hline Shrimps & $\begin{array}{l}\text { The samples were inoculated with Vibrio } \\
\text { parahaemolyticus and subsequently treated } \\
\text { using AEW1, with } 51 \mathrm{mg} / \mathrm{L} \text { chlorine, } \\
\text { AEW2, with } 78 \mathrm{mg} / \mathrm{L} \text { chlorine, or organic } \\
\text { acids (2\% AA and } 2 \% \text { LA), for } 1 \text { min or } \\
5 \text { min under different } \\
\text { treatment conditions. }\end{array}$ & V. parahaemolyticus \\
\hline $\begin{array}{c}\text { Shrimp } \\
\text { (Litopenaeus vannamei) }\end{array}$ & $\begin{array}{l}\text { AEW was obtained by electrolysis of a } \\
0.1 \% \text { sodium chloride solution using a } \\
\text { strongly acidic electrolyte water } \\
\text { generator. AEW was frozen for } 24 \mathrm{~h}\end{array}$ & Total viable count \\
\hline
\end{tabular}

Tested Microorganisms

Coliform

Pseudomonas spp.
Total aerobic counts neutral pH $(7.0 \pm 0.1)$ and a residual chloride level of $<0.5 \%$. The solution was diluted to $50 \%$ and $15 \%(\mathrm{v} / \mathrm{v})$.

Two types of acidic electrolyzed wate (AEW) were used for treatment time, strong (SAEW), with an available chlorin concentration of $20 \mathrm{mg} / \mathrm{L}, \mathrm{pH} 3.1$ and an oxidation-reduction potential of $1150 \mathrm{mV}$ and weak (WAEW), with $10 \mathrm{mg} / \mathrm{L}$ of lorine, $\mathrm{pH} 3.55$ and potential of $950 \mathrm{mV}$.
Escherichia coli O104:H4

Listeria monocytogenes Aeromonas hydrophila Vibrio parahaemolyticus

Campylobacter jejuni

in

Limit

Reference

The use of the $15 \%$ or $50 \%$ solution for treatment significantly reduced microbiota (approx. 1-2 log colony-forming units) during storage and significantly extended the shelf-life of the fillets by 2 and 4 days, without affecting the overall quality of the fillets, both raw and cooked.

No negative effects were found instead, the significant increase in shelf-life and quality of fillets was corroborated by raw an cooked sensory evaluation.

SAEW and WAEW showed significant inhibitory activity against inoculated bacteria in each shellfish species. SAEW showed the highest antimicrobial activity with reductions from 1.4 to 2.2 logarithmic cycles for the different microorganisms.

Weak electrolysed water showe fewer effective results than strong electrolysed water.

AEW and NEW showed strong antimicrobial properties against $L$. monocytogenes. The initial inoculation was $7.9 \log \mathrm{CFU} / \mathrm{g}$, which was reduced to $2.3 \log \mathrm{CFU} / \mathrm{g}$ in samples treated with NEW at $65^{\circ} \mathrm{C}$ for $10 \mathrm{~min}$. By increasing the temperature and exposure time, the efficacy

of electrolysed water increased significantly.
Further studies are needed on the effect of NEW and mild heat treatment on lipid oxidation changes in amino acids, nutritional value and product preservation.
AEW treatment at $50^{\circ} \mathrm{C}$ revealed a $3.1 \mathrm{log}$ $\mathrm{CFU} / \mathrm{g}$ reduction in V. parahaemolyticus.
The treatment significantly influenced the physico-chemical properties ( $\mathrm{pH}, \mathrm{ORP}, \mathrm{ACC})$.

AEW ice was able to inactivate the bacterial

load on raw shrimp; the total viable

bacterial populations were reduced by

$1.5 \log \mathrm{CFU} / \mathrm{g}$ after $24 \mathrm{~h}$. AEW ice also

inhibited TVBN formation and PPO activity. 
Table 4. Cont.

Fish Product Treatment Conditions

The electrolyzed oxidizing water (EOW) was generated with $\mathrm{NaCl}(0.1 \%)$ and deionised water, with a $\mathrm{pH}$ of 2.4 , a

American shad (Alosa sapidissima) potential of $1185 \mathrm{mV}$ and a free chlorine level of 70 and $80 \mathrm{ppm}$. Dietary chitosan was used as a $2 \%(\mathrm{w} / \mathrm{v})$ coating solution.

Total viable count

In this study, weakly acidic electrolyzed water (WAEW) was used in combination with the modified atmosphere packagin (MAP). The WAEW had a $\mathrm{pH}$ of 6.4 and

Pacific white shrimp between 520 and $540 \mathrm{mV}$ and an available chlorine concentration of 6.4 and $6.5 \mathrm{mg} / \mathrm{L}$.

Acid electrolyte oxidising water $(\mathrm{pH} 2.30$ water was tested for 0 (control) $1,3,5$ and $10 \mathrm{~min}$ at $22^{\circ} \mathrm{C}$.

Total aerobic count 6.6 , an oxidation-reduction potential

Tested Microorganisms

Results

The results of microbiological

physico-chemical ( $\mathrm{pH}, \mathrm{TVBN}, \mathrm{TBA}$, texture and colour) and sensory analyses revealed that the combined treatment successfully inhibited microbial growth, protein degradation and lipid oxidation and did not change texture, colour, or sensory characteristics during storage. This

treatment extended the shelf-life of

American shad fillets by $9-10$ days during refrigerated storage.

WAEW and MAP $\left(40 \% \mathrm{CO}_{2}, 0 \% \mathrm{O}_{2}, 50 \%\right.$ $\mathrm{N}_{2} ; 30 \% \mathrm{CO}_{2}, 20 \% \mathrm{O}_{2}, 50 \% \mathrm{~N}_{2}$ ) exerted a significant effect on spoilage inhibition, colve Staphylococcus aureus

$$
\text { of sensory properties. }
$$

The use of AC-EW was found to be the
E. coli $\mathrm{O} 157: \mathrm{H7}$ Salmonella Typhimurium L. monocytogenes O157:H7, S. Typhinurium and L monocytogenes. The level of reduction ranged between ca. 1.5 and $1.6 \operatorname{logs}$ for $E$. coli O157:H7 and $S$. Typhimurium, and 1.1-1.3 logs reduction for $L$. monocytogenes
Cold smoked atlantic salmon (Salmon salar) and free chlorine $38 \mathrm{ppm}$ ), sterile distilled

Treatment prior to cold smoking at $40{ }^{\circ} \mathrm{C}$ Electrolysed water (pH 2.7; ORP $1150 \mathrm{mV}$ free chlorine $60 \mathrm{ppm}$ ) was generated at 9 and $12 \mathrm{~V}$ DC for $15 \mathrm{~min}$. Samples noculated with the target bacteria, were (20,30 and $\left.40^{\circ} \mathrm{C}\right)$ and at different times

$$
\text { (2, } 6 \text { and } 10 \mathrm{~min}) \text {. }
$$

for $10 \mathrm{~min}$ was able to reduce the cellular load of L. monocytogenes by $2.85 \log \mathrm{CFU} / \mathrm{g}$ without causing any significant change in

No negative effects

L. monocytogenes sensory properties.

There was no complete elimination of inoculated pathogens after treatment.

SAEW ice has been shown to be able to inhibit bacterial reproduction during The slightly acidic electrolyzed water Squid an aqueous mixture containing $0.2 \% \mathrm{NaCl}$ and $0.04 \% \mathrm{HCl}$, then frozen immediately.
Endogenous microbiota 
Table 4. Cont.

Fish Product

Electrolytic acidified water (AEW) was obtained at a constant current of $10 \mathrm{~A}$ by electrolysis of a sodium chloride solution

Raw salmon fillets $(0.1 \%, \mathrm{w} / \mathrm{v}), \mathrm{pH}(2.6 \pm 0.2)$ and $0.1140 \pm 30 \mathrm{mV}$. The fillets were treated for 1,5 , or $10 \mathrm{~min}$ at room temperature.

Near-neutral electrolysed water (anolyte) ( $\mathrm{pH} 6.0$ to $6.5 \pm 0.02$; oxidation reduction potential > $700 \mathrm{mV}$; residual chlorine concentration of 10 to $200 \mathrm{ppm}$ ) was applied for $3 \mathrm{~min}$.

AEW was prepared by electrolysis of $0.1 \%$ sodium chloride $(\mathrm{NaCl})$ solution

Shrimps

$$
\text { and frozen. }
$$

L. monocytogenes

Natural microbiota
L monocytogenes isms

Results

The treatment reduced microbial contamination; with reductions of $0.75-0.79$ $\log \mathrm{CFU} / \mathrm{g}$ for L. monocytogenes (compared to $0.17 \mathrm{log}$ CFU $/ \mathrm{g}$ in control) and about $0.59-0.64 \log$ CFU/g for total viable count.

Treatment with anolyte resulted in a $1 \mathrm{log}$ reduction for Salmonella and this reduction was maintained even after 8 days of refrigerated storage.

AEW ice showed a good ability to limit $\mathrm{pH}$ and colour changes and the formation of total volatile basic nitrogen (TVBN) Bacterial growth was controlled (reduction $>1.0 \log \mathrm{CFU} / \mathrm{g}$, i.e., $>90 \%$ ) after 6 days.
The WAEW was generated by acid $(3 \%)$. The hypochlorous acid content oxidation-reduction potential and $\mathrm{pH}$ value were $21 \mathrm{ppm}, 947.6 \mathrm{mV}$ and 6.1 respectively. The treatment was

Farmed puffer fish combined with modified atmosphere and vacuum packaging.

Slightly acidic electrolysed water was

produced by electrolysis of a $6 \% \mathrm{HCl}$

Brown sole

(Pleuronectes herzensteini) electrolysing a solution of hydrochloric solution and used in combination with a

$5 \% w / v$ grapefruit seed extract solution after freezing.
A strong deterioration in the sensory quality of the product was observed; the colour and

odour of salmon were

significantly affected after

treatments, whereas the texture

nd firmness of tissue were not

significantly changed.

\section{No reduction in L. monocytogenes}

was observed.
Autochthonous microbiota
Total viable count

$\mathrm{H}_{2} \mathrm{~S}$-producing bacteria

The combined effect of WAEW and MAP of

most effective in maintaining better quality

Pseudomonas spp. and prolonging shelf-life to 18 days against 9 days of untreated samples.

Lactic acid bacteria
Microbial growth was controlled, shelf-life

Pseudomonas spp

Total viable count

was extended to $12-13$ days and sensory characteristics were improved.

No negative effects were found.

were observed.

\section{No negative effects}

$\mathrm{H}_{2} \mathrm{~S}$-producing bacteria

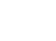




\section{Some Critical Considerations}

Nowadays, consumers continue to demand healthy foods which must be safe while preserving their naturalness. To meet this trend, the food industry could find a precious ally in non-thermal food processing technologies, especially those discussed in this review. In fact, against the negative effects associated with thermal food processing methods, i.e., the high operational costs and alteration of food nutrient components, innovative non-thermal food processing methods are able to cause microbiological inactivation without or with little use of heat.

In general, all the innovative methods analysed in this review have shown a good effectiveness in the control microbial growth in fish products, maintaining their organoleptic, nutritional and sensory characteristics. In addition, these technologies have the great advantage to have a lower energy consumption and shorter production times. On the other hand, their application has already some limitations, as not all these methods are in the same development stage. Each method, as also shown in Figure 1, has some benefits and some issues to address; moreover, some of them exerted a mild effect, while, for others, the extent of antimicrobial effect is higher.
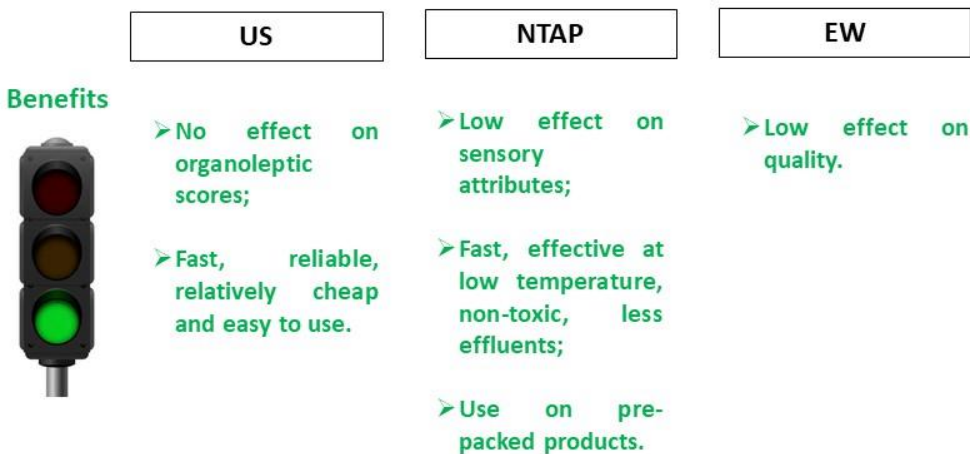

Issues

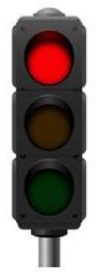

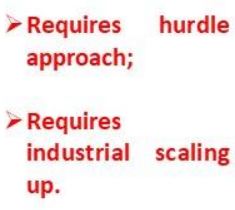

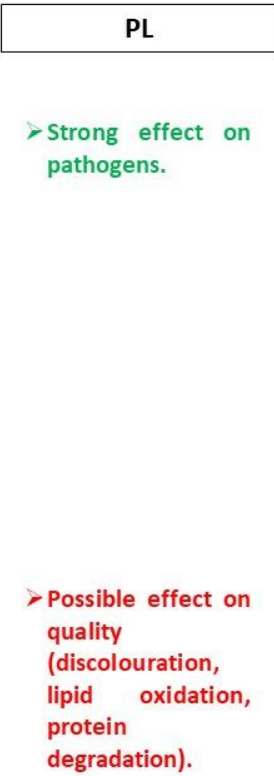

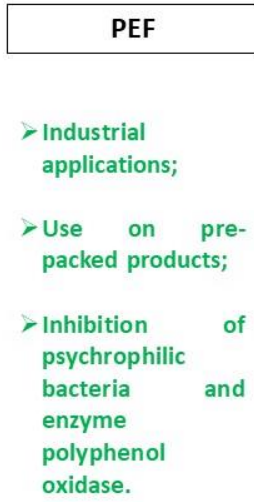

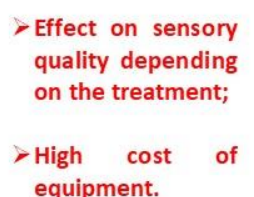

Figure 1. Benefits and issues of non-thermal approaches to prolong the shelf-life of fish. US, ultrasound; NTAP, non-thermal atmospheric plasma; EW, electrolyzed water; PL, pulsed light; PEF, pulsed electric field.

In particular, as mentioned above, a strong limitation of NTAP is lipid oxidation, but some recent studies have demonstrated that this negative aspect could be minimised by using antioxidant compounds in combination [24-26,34,35].

US and EW, used individually, do not particularly influence the sensory parameters of fish products, but do not lead to a significant decrease in microbial load. Additionally, in this case, a hurdle approach suggests that the antimicrobial action could be enhanced by combining the cavitation effect of US and the chlorine effect of EW [122]. All the analysed techniques could also be combined with modified atmosphere (MAP), or the addition of antimicrobial compounds on functional edible films, which would improve the sensory parameters and microbiological quality of the fish products [122].

Data reported in the literature point out that the decontamination effect of PEF is low; moreover, this technique appears not suitable for fish products, due to the structural changes it may produce [67]. In contrast, using PEF to extract bioactive compounds from fish waste is promising [57]. 
An overall analysis allows us to define the following key-points:

1. The use of NTAP in fish products is limited by the synthesis of off-flavours and off-odours compounds (due to lipid oxidation) that affect the product quality;

2. PEF, similar to US, applied to pre-packed and liquid fish products, has shown a great potential to produce high quality products maintaining optimal appearance and sensory attributes. However, it has been little explored and further studies should be performed to consider a suitable application in fish industries;

3. PL is able to inactivate important pathogens, such as L. monocytogenes, E. coli and Salmonella spp., but it greatly compromises the sensory quality;

4. EW studies have shown minor quality degradation compared with other treatments, highlighting EW as the most promising technology;

5. The synergistic effects among non-thermal and other technologies showed great potentials in the fish industry, enhancing the product quality throughout the application of hurdle technology;

6. From an economic point of view, US technology should be extremely beneficial for fish processors.

\section{Conclusions}

Non-thermal technologies developed in recent decades have received much attention in the food industry, showing great potential compared to traditional preservation methods, although some limitations with respect to sensory attributes have been highlighted when used under extreme working conditions.

These limitations could be overcome by using the technologies in a synergistic and combined way, thus increasing microbiological safety and sensory quality. However, further studies are needed to implement these technologies on an industrial level, as many of them are still used on a laboratory scale.

Future investigations should be aimed to develop one (or more) hurdle-like nonthermal method combining different processing methods in order to help the food industries to choose the best technology that meets their food production requirements and the modern consumers' demand.

Author Contributions: Conceptualization, B.S. and M.R.C.; investigation, A.R., V.B., E.M., P.M. and R.S.; writing—original draft preparation, A.R., B.S., V.B., E.M. and P.M.; writing-review and editing, B.S. and A.B.; funding acquisition, M.S. and G.S. All authors have read and agreed to the published version of the manuscript.

Funding: This research study was funded by the Puglia region through the project PO FEAMP 2014/2020-Measure 1.26 "Valorizzazione di specie ittiche affumicate mediante tecniche tradizionali e innovative" (CUP N. B71B17000990009; Project leader: UNCI-Agroalimentare).

Data Availability Statement: Not Applicable.

Acknowledgments: All the authors gratefully acknowledge the assistance of Vincenza Iadevaia for her administrative and technical support.

Conflicts of Interest: The authors declare no conflict of interest.

\section{References}

1. Castro, P.; Huber, M.E. Marine Biology, 9th ed.; McGraw-Hill Companies: New York, NY, USA, 2013.

2. Mohanty, B.P.; Mahanty, A.; Ganguly, S.; Mitra, T.; Karunakaran, D.; Anandan, R. Nutritional composition of food fishes and their importance in providing food and nutritional security. Food Chem. 2019, 293, 561-570. [CrossRef] [PubMed]

3. Oehlenschläger, J.; Sörensen, N.K. Criteria of sea fish freshness and quality aspects in seafoods. In Proceedings of the Final Meeting of the Concerted Action "Evaluation of Fish Freshness", Nantes, France, 12-14 November 1997; pp. $30-35$.

4. Ghaly, A.E.; Dave, D.; Budge, S.; Brooks, M.S. Fish Spoilage Mechanisms and Preservation Techniques: Review. Am. J. Appl. Sci. 2010, 7, 859-877. [CrossRef]

5. Fraser, O.; Sumar, S. Compositional changes and spoilage in fish. Nutr. Food Sci. 1998, 5, 275-279. [CrossRef]

6. Biji, K.B.; Ravishankar, C.N.; Venkateswarlu, R.; Mohan, C.; Gopal, T.K.S. Biogenic amines in seafood: A review. J. Food Sci. Technol. 2016, 53, 2210-2218. [CrossRef] [PubMed] 
7. Antoine, F.; Wei, C.; Littell, R.; Quinn, B.; Hogle, A.; Marshall, M. Free Amino Acids in Dark- and White-muscle Fish as Determined by O-phthaldialdehyde Precolumn Derivatization. J. Food Sci. 2001, 66, 72-77. [CrossRef]

8. Kim, S.; Price, R.; Morrissey, M.; Field, K.; Wei, C.; An, H. Histamine Production by Morganella morganii in Mackerel, Albacore, Mahi-mahi, and Salmon at Various Storage Temperatures. J. Food Sci. 2002, 67, 1522-1528. [CrossRef]

9. Dalgaard, P.; Madsen, H.; Samieian, N.; Emborg, J. Biogenic amine formation and microbial spoilage in chilled garfish (Belone belone belone)-effect of modified atmosphere packaging and previous frozen storage. J. Appl. Microbiol. 2006, 101, 80-95. [CrossRef]

10. Kim, S.H.; Wei, C.; Clemens, R.A.; An, H. Histamine accumulation in seafoods and its control to prevent outbreaks of scombroid poisoning. J. Aquat. Food Prod. Technol. 2004, 13, 81-100. [CrossRef]

11. Karunasagar, I. Bacterial pathogens associated with aquaculture products. In Zoonoses-Infections Affecting Humans and Animals; Sing, A., Ed.; Springer: Berlin/Heidelberg, Germany, 2015; pp. 125-158.

12. Novoslavskij, A.; Terentjeva, M.; Eizenberga, I.; Valcina, O.; Bartkevics, V.; Bērzinšs, A. Major foodborne pathogens in fish and fish products: A review. Ann. Microbiol. 2015, 66, 1-15. [CrossRef]

13. Kalkan, S.; Altuğ, G. The composition of cultivable bacteria, bacterial pollution, and environmental variables of the coastal areas: An example from the Southeastern Black Sea, Turkey. Environ. Monit. Assess. 2020, 192, 1-23. [CrossRef]

14. Klase, G.; Lee, S.; Liang, S.; Kim, J.; Zo, Y.G.; Lee, J. The microbiome and antibiotic resistance in integrated fish farm water: Implications of environmental public health. Sci. Total Environ. 2019, 649, 1491-1501. [CrossRef]

15. Huis in 't Veld, J.H. Microbial and biochemical spoilage of foods: An overview. Int. J. Food Microbiol. 1996, 33, 1-18. [CrossRef]

16. Pereira, R.; Vicente, A. Environmental impact of novel thermal and non-thermal technologies in food processing. Food Res. Int. 2010, 43, 1936-1943. [CrossRef]

17. Fukuda, S.; Kawasaki, Y.; Izawa, S. Ferrous chloride and ferrous sulfate improve the fungicidal efficacy of cold atmospheric argon plasma on melanized Aureobasidium pullulans. J. Biosci. Bioeng. 2019, 128, 28-32. [CrossRef] [PubMed]

18. Park, S.Y.; Ha, S.-D. Application of cold oxygen plasma for the reduction of Cladosporium cladosporioides and Penicillium citrinum on the surface of dried filefish (Stephanolepis cirrhifer) fillets. Int. J. Food Sci. Technol. 2014, 50, 966-973. [CrossRef]

19. Shaw, A.; Shama, G.; Iza, F. Emerging applications of low temperature gas plasmas in the food industry. Biointerphases 2015, 10, 029402. [CrossRef] [PubMed]

20. von Woedtke, T.; Reuter, S.; Masur, K.; Weltmann, K.D. Plasmas for medicine. Phys. Rep. 2013, 530, 291-320. [CrossRef]

21. Moutiq, R.; Misra, N.; Mendonça, A.; Keener, K. In-package decontamination of chicken breast using cold plasma technology: Microbial, quality and storage studies. Meat Sci. 2019, 159, 107942. [CrossRef] [PubMed]

22. Hojnik, N.; Cvelbar, U.; Tavčar-Kalcher, G.; Walsh, J.L.; Križaj, I. Mycotoxin Decontamination of Food: Cold Atmospheric Pressure Plasma versus "Classic" Decontamination. Toxins 2017, 9, 151. [CrossRef]

23. Olatunde, O.O.; Benjakul, S.; Vongkamjan, K. Combined effects of high voltage cold atmospheric plasma and antioxidants on the qualities and shelf-life of Asian sea bass slices. Innov. Food Sci. Emerg. Technol. 2019, 54, 113-122. [CrossRef]

24. Olatunde, O.O.; Benjakul, S.; Vongkamjan, K. High voltage cold atmospheric plasma: Antibacterial properties and its effect on quality of Asian sea bass slices. Innov. Food Sci. Emerg. Technol. 2019, 52, 305-312. [CrossRef]

25. Shiekh, K.A.; Benjakul, S. Effect of pulsed electric field treatments on melanosis and quality changes of Pacific white shrimp during refrigerated storage. J. Food Process. Preserv. 2019, 44. [CrossRef]

26. Olatunde, O.O.; Benjakul, S.; Vongkamjan, K. Shelf-life of refrigerated Asian sea bass slices treated with cold plasma as affected by gas composition in packaging. Int. J. Food Microbiol. 2020, 324, 108612. [CrossRef]

27. Puligundla, P.; Choi, S.; Mok, C. Microbial Decontamination of Gwamegi (Semi-dried Pacific Saury) Using Corona Discharge Plasma Jet, Including Physicochemical and Sensory Evaluation. J. Aquat. Food Prod. Technol. 2017, 27, 274-283. [CrossRef]

28. Hajhoseini, A.; Sharifan, A.; Yousefi, H. Effects of atmospheric cold plasma on microbial growth of Listeria innocua and Staphylococcus aureus in ready-to-eat fish products. Iran. J. Fish. Sci. 2019, 19, 262-271. [CrossRef]

29. Choi, S.; Puligundla, P.; Mok, C. Effect of corona discharge plasma on microbial decontamination of dried squid shreds including physico-chemical and sensory evaluation. LWT 2017, 75, 323-328. [CrossRef]

30. Choi, M.-S.; Jeon, E.B.; Kim, J.Y.; Choi, E.H.; Lim, J.S.; Choi, J.; Park, S.Y. Impact of non-thermal dielectric barrier discharge plasma on Staphylococcus aureus and Bacillus cereus and quality of dried blackmouth angler (Lophiomus setigerus). J. Food Eng. 2020, 278, 109952. [CrossRef]

31. Albertos, I.; Martin-Diana, A.B.; Cullen, P.; Tiwari, B.K.; Ojha, K.S.; Bourke, P.; Rico, D. Shelf-life extension of herring (Clupea harengus) using in-package atmospheric plasma technology. Innov. Food Sci. Emerg. Technol. 2019, 53, 85-91. [CrossRef]

32. Zhao, Y.; Ojha, S.; Burgess, C.M.; Sun, D.; Tiwari, B.K. Influence of various fish constituents on inactivation efficacy of plasmaactivated water. Int. J. Food Sci. Technol. 2020, 55, 2630-2641. [CrossRef]

33. Olatunde, O.O.; Benjakul, S.; Vongkamjan, K. Dielectric Barrier Discharge High Voltage Cold Atmospheric Plasma: An Innovative Nonthermal Technology for Extending the Shelf-Life of Asian Sea Bass Slices. J. Food Sci. 2019, 84, 1871-1880. [CrossRef]

34. Singh, A.; Benjakul, S. The combined effect of squid pen chitooligosaccharides and high voltage cold atmospheric plasma on the shelf-life extension of Asian sea bass slices stored at $4{ }^{\circ}$ C. Innov. Food Sci. Emerg. Technol. 2020, 64, 102339. [CrossRef]

35. Singh, A.; Benjakul, S.; Olatunde, O.O.; Yesilsu, A.F. The Combined Effect of Squid Pen Chitooligosaccharide and High Voltage Cold Atmospheric Plasma on the Quality of Asian Sea Bass Slices Inoculated with Pseudomonas aeruginosa. Turk. J. Fish. Aquat. Sci. 2020, 21, 41-50. [CrossRef] 
36. Mandal, R.; Singh, A.; Singh, A.P. Recent developments in cold plasma decontamination technology in the food industry. Trends Food Sci. Technol. 2018, 80, 93-103. [CrossRef]

37. Koddy, J.K.; Miao, W.; Hatab, S.; Tang, L.; Xu, H.; Nyaisaba, B.M.; Chen, M.; Deng, S. Understanding the role of atmospheric cold plasma (ACP) in maintaining the quality of hairtail (Trichiurus Lepturus). Food Chem. 2020, 343, 128418. [CrossRef]

38. Nyaisaba, B.M.; Miao, W.; Hatab, S.; Siloam, A.; Chen, M.; Deng, S. Effects of cold atmospheric plasma on squid proteases and gel properties of protein concentrate from squid (Argentinus ilex) mantle. Food Chem. 2019, 291, 68-76. [CrossRef]

39. Silva, D.A.D.S.; Campelo, M.C.D.S.; Rebouças, L.D.O.S.; Vitoriano, J.D.O.; Alves, C.; Da Silva, J.B.A.; Lima, P.D.O. Use of Cold Atmospheric Plasma To Preserve the Quality of White Shrimp (Litopenaeus vannamei). J. Food Prot. 2019, 82, 1217-1223. [CrossRef] [PubMed]

40. Miao, W.; Nyaisaba, B.M.; Koddy, J.K.; Chen, M.; Hatab, S.; Deng, S. Effect of cold atmospheric plasma on the physicochemical and functional properties of myofibrillar protein from Alaska pollock (Theragra chalcogramma). Int. J. Food Sci. Technol. 2019, 55, 517-525. [CrossRef]

41. Panpipat, W.; Chaijan, M. Effect of Atmospheric Pressure Cold Plasma on Biophysical Properties and Aggregation of Natural Actomyosin from Threadfin Bream (Nemipterus bleekeri). Food Bioprocess Technol. 2020, 13, 851-859. [CrossRef]

42. Albertos, I.; Martín-Diana, A.; Cullen, P.; Tiwari, B.K.; Ojha, S.; Bourke, P.; Álvarez, C.; Rico, D. Effects of dielectric barrier discharge (DBD) generated plasma on microbial reduction and quality parameters of fresh mackerel (Scomber scombrus) fillets. Innov. Food Sci. Emerg. Technol. 2017, 44, 117-122. [CrossRef]

43. Chen, J.; Wang, S.Z.; Chen, J.Y.; Chen, D.Z.; Denga, S.G.; Xua, B. Effect of cold plasma on maintaining the quality of chub mackerel (Scomber japonicus): Biochemical and sensory attributes. J. Sci. Food Agric. 2018, 99, 39-46. [CrossRef] [PubMed]

44. Colejo, S.; Alvarez-Ordóñez, A.; Prieto, M.; González-Raurich, M.; López, M. Evaluation of ultraviolet light (UV), non-thermal atmospheric plasma (NTAP) and their combination for the control of foodborne pathogens in smoked salmon and their effect on quality attributes. Innov. Food Sci. Emerg. Technol. 2018, 50, 84-93. [CrossRef]

45. Esua, O.J.; Cheng, J.-H.; Sun, D.-W. Antimicrobial activities of plasma-functionalized liquids against foodborne pathogens on grass carp (Ctenopharyngodon Idella). Appl. Microbiol. Biotechnol. 2020, 104, 9581-9594. [CrossRef]

46. Zimmermann, U.; Pilwat, G.; Riemann, F. Dielectric Breakdown of Cell Membranes. Biophys. J. 1974, 14, 881-899. [CrossRef]

47. Zderic, A.; Zondervan, E.; Meuldijk, J. Breakage of cellular tissue by pulsed electric field: Extraction of polyphenols from fresh tea leaves. Chem. Eng. Trans. 2013, 32, 1795-1800.

48. Angesbach, A.; Heinz, V.; Knorr, D. Effects of pulsed electric fields on cell membranes in real food systems. Innov. Food Sci. Emerg. Technol. 2000, 1, 135-149. [CrossRef]

49. Farahnaky, A.; Azizi, R.; Gavahian, M. Accelerated texture softening of some root vegetables by Ohmic heating. J. Food Eng. 2012, 113, 275-280. [CrossRef]

50. Gavahian, M.; Chu, Y.-H.; Farahnaky, A. Effects of ohmic and microwave cooking on textural softening and physical properties of rice. J. Food Eng. 2018, 243, 114-124. [CrossRef]

51. Oziembłowski, M.; Kopeć, W. Pulsed Electric Fields (PEF) as an unconventional method of food preservation. Pol. J. Food Nutr. Sci. 2005, 14, 31-35.

52. Pourzaki, A.; Mirzaee, H. Pulsed electric field generators in food processing. In Proceedings of the 18th National Congress on Food Technology, Mashhad, Iran, 17-19 December 2008; pp. 1-7.

53. Gudmundsson, M.; Hafsteinsson, H. Effect of electric field pulses on microstructure of muscle foods and roes. Trends Food Sci. Technol. 2001, 12, 122-128. [CrossRef]

54. Klonowski, I.; Heinz, V.; Toepfl, S.; Gunnarsson, G.; Porkelsson, G. Applications of Pulsed Electric Field Technology for the Food Industry; Report 06; Iceland Fishes Laboratory, Rannsóknastofnun Fiskiðnaðarins: Reykjavík, Iceland, 2006.

55. Adeomowaye, B.I.O.; Angersbach, A.; Taiwo, K.A.; Knorr, D. Use of pulsed electric field pre-treatment to improved hydration characteristics of plant-based foods. Trends Food Sci. Tech. 2001, 12, 285-295. [CrossRef]

56. Taiwo, K.; Angersbach, A.; Knorr, D. Influence of high intensity electric field pulses and osmotic dehydration on the rehydration characteristics of apple slices at different temperatures. J. Food Eng. 2002, 52, 185-192. [CrossRef]

57. He, G.; Yin, Y.; Yan, X.; Yu, Q. Optimisation extraction of chondroitin sulfate from fish bone by high intensity pulsed electric fields. Food Chem. 2014, 164, 205-210. [CrossRef]

58. Zhou, Y.; He, Q.; Zhou, D. Optimization extraction of protein from mussel by high-intensity pulsed electric fields. J. Food Process. Preserv. 2017, 41, e12962. [CrossRef]

59. Zhou, Y.; Sui, S.; Huang, H.; He, G.; Wang, S.; Yin, Y.; Ma, Z. Process optimization for extraction of fishbone calcium assisted by high intensity pulsed electric fields. Nongye Gongcheng Xuebao-Trans Chin. Soc. Agricul. Eng. 2012, 28, $265-270$.

60. Li, M.; Lin, J.; Chen, J.; Fang, T. Pulsed Electric Field-Assisted Enzymatic Extraction of Protein from Abalone (Haliotis Discus HannaiIno) Viscera. J. Food Process. Eng. 2015, 39, 702-710. [CrossRef]

61. Barba, F.J.; Koubaa, M.; do Prado-Silva, L.; Orlien, V.; Sant'Ana, A.D.S. Mild processing applied to the inactivation of the main foodborne bacterial pathogens: A review. Trends Food Sci. Technol. 2017, 66, 20-35. [CrossRef]

62. Horita, C.N.; Baptista, R.C.; Caturla, M.Y.R.; Lorenzo, J.M.; Barba, F.J.; Sant'Ana, A.D.S. Combining reformulation, active packaging and non-thermal post-packaging decontamination technologies to increase the microbiological quality and safety of cooked ready-to-eat meat products. Trends Food Sci. Technol. 2018, 72, 45-61. [CrossRef]

63. Kumar, Y.; Kumar, K.; Patel, V. Pulsed electric field processing in food technology. Int. J. Eng. Stu. Tech. App. 2015, 1, 6-16. 
64. Caminiti, I.M.; Palgan, I.; Noci, F.; Muñoz, A.; Whyte, P.; Cronin, D.A.; Morgan, D.J.; Lyng, J.G. The effect of pulsed electric fields (PEF) in combination with high intensity light pulses (HILP) on Escherichia coli inactivation and quality attributes in apple juice. Innov. Food Sci. Emerg. Technol. 2011, 12, 118-123. [CrossRef]

65. Stoica, M.; Mihalcea, L.; Borda, D.; Alexe, P. Nonthermal novel food processing technologies: An overview. J. Agroaliment. Process. Technol. 2013, 19, 212-217.

66. Jaeger, H.; Meneses, N.; Moritz, J.; Knorr, D. Model for the differentiation of temperature and electric field effects during thermal assisted PEF processing. J. Food Eng. 2010, 100, 109-118. [CrossRef]

67. Gómez, B.; Munekata, P.E.S.; Gavahian, M.; Barba, F.J.; Martí-Quijal, F.J.; Bolumar, T.; Campagnol, P.C.B.; Tomašević, I.; Lorenzo, J.M. Application of pulsed electric fields in meat and fish processing industries: An overview. Food Res. Int. 2019, 123, 95-105. [CrossRef]

68. Dunn, J.; Ott, T.; Clark, W. Pulsed-light treatment of food and packaging. Food Technol. 1995, 49, 95-98.

69. Food and Drug Administration. Code of Federal Regulations; 21CFR179.41; FDA: Silver Spring, MD, USA, 1996.

70. Mandal, R.; Mohammadi, X.; Wiktor, A.; Singh, A.; Singh, A.P. Applications of Pulsed Light Decontamination Technology in Food Processing: An Overview. Appl. Sci. 2020, 10, 3606. [CrossRef]

71. Anderson, J.G.; Rowan, N.; MacGregor, S.J.; Fouracre, R.A.; Farish, O. Inactivation of food-borne enteropathogenic bacteria and spoilage fungi using pulsed-light. IEEE Trans. Plasma Sci. 2000, 28, 83-88. [CrossRef]

72. Gomez-Lopez, V.; Devlieghere, F.; Bonduelle, V.; Debevere, J. Factors affecting the inactivation of micro-organisms by intense light pulses. J. Appl. Microbiol. 2005, 99, 460-470. [CrossRef]

73. Lasagabaster, A.; de Maranòn, I.M. Impact of process parameters on Listeria innocua inactivation kinetics by pulsed light technology. Food Bioprocess Technol. 2013, 6, 1828-1836. [CrossRef]

74. Artıguez, M.L.; de Maranòn, I.M. Process parameters affecting Listeria innocua inactivation by pulsed light. Food Bioprocess Technol. 2014, 7, 2759-2765. [CrossRef]

75. Ozer, N.P.; Demirci, A. Inactivation of Escherichia coli O157:H7 and Listeria monocytogenes inoculated on raw salmon fillets by pulsed UV-light treatment. Int. J. Food Sci. Technol. 2005, 41, 354-360. [CrossRef]

76. Earnshaw, R.; Appleyard, J.; Hurst, R. Understanding physical inactivation processes: Combined preservation opportunities using heat, ultrasound and pressure. Int. J. Food Microbiol. 1995, 28, 197-219. [CrossRef]

77. Earnshaw, R.G. Ultrasound: A new opportunity for food preservation. In Ultrasound in Food Processing; Povey, M.J.W., Mason, T.J., Eds.; Blackie Academic and Professional: London, UK, 1998; pp. 183-192.

78. Butz, P.; Tauscher, B. Emerging technologies: Chemical aspects. Food Res. Int. 2002, 35, 279-284. [CrossRef]

79. Fellows, P. Food Processing Technology: Principles and Practice, 2nd ed.; CRC Press: New York, NY, USA, 2000.

80. Adekunte, A.; Valdramidis, V.; Tiwari, B.; Slone, N.; Cullen, P.; Donnell, C.; Scannell, A. Resistance of Cronobacter sakazakii in reconstituted powdered infant formula during ultrasound at controlled temperatures: A quantitative approach on microbial responses. Int. J. Food Microbiol. 2010, 142, 53-59. [CrossRef]

81. Ojha, K.S.; Mason, T.J.; O’Donnell, C.P.; Kerry, J.P.; Tiwari, B.K. Ultrasound technology for food fermentation applications. Ultrason. Sonochemistry 2017, 34, 410-417. [CrossRef] [PubMed]

82. Mikš-Krajnik, M.; Feng, L.X.J.; Bang, W.S.; Yuk, H.-G. Inactivation of Listeria monocytogenes and natural microbiota on raw salmon fillets using acidic electrolyzed water, ultraviolet light or/and ultrasounds. Food Control. 2017, 74, 54-60. [CrossRef]

83. Rosario, D.K.A.; Rodrigues, B.L.; Bernardes, P.C.; Conte-Junior, C.A. Principles and applications of non-thermal technologies and alternative chemical compounds in meat and fish. Crit. Rev. Food Sci. Nutr. 2020, 61, 1163-1183. [CrossRef] [PubMed]

84. Gulzar, S.; Benjakul, S. Ultrasound Waves Increase the Yield and Carotenoid Content of Lipid Extracted From Cephalothorax of Pacific White Shrimp (Litopenaeus vannamei). Eur. J. Lipid Sci. Technol. 2018, 120. [CrossRef]

85. Sinthusamran, S.; Benjakul, S.; Kijroongrojana, K.; Prodpran, T.; Agustini, T.W. Yield and chemical composition of lipids extracted from solid residues of protein hydrolysis of Pacific white shrimp cephalothorax using ultrasound-assisted extraction. Food Biosci. 2018, 26, 169-176. [CrossRef]

86. Brasil, C.C.B.; Barin, J.S.; Jacob-Lopes, E.; Menezes, C.R.; Zepka, L.Q.; Wagner, R.; Campagnol, P.C.B.; Cichoski, A.J. Single step non-thermal cleaning/sanitation of knives used in meat industry with ultrasound. Food Res. Int. 2017, 91, 133-139. [CrossRef]

87. Shimizu, Y.; Hurusawa, T. Antiviral, antibacterial, and antifungal actions of electrolyzed oxidizing water through electrolysis. Dent. J. 1992, 37, 1055-1062.

88. Hsu, S.-Y. Effects of flow rate, temperature and salt concentration on chemical and physical properties of electrolyzed oxidizing water. J. Food Eng. 2005, 66, 171-176. [CrossRef]

89. Kiura, H.; Sano, K.; Morimatsu, S.; Nakano, T.; Morita, C.; Yamaguchi, M.; Maeda, T.; Katsuoka, Y. Bactericidal activity of electrolyzed acid water from solution containing sodium chloride at low concentration, in comparison with that at high concentration. J. Microbiol. Methods 2002, 49, 285-293. [CrossRef]

90. Vorobjeva, N.V.; Vorobjeva, L.I.; Khodjaev, E.Y. The Bactericidal Effects of Electrolyzed Oxidizing Water on Bacterial Strains Involved in Hospital Infections. Artif. Organs 2004, 28, 590-592. [CrossRef] [PubMed]

91. Park, H.; Hung, Y.-C.; Chung, D. Effects of chlorine and $\mathrm{pH}$ on efficacy of electrolyzed water for inactivating Escherichia coli O157:H7 and Listeria monocytogenes. Int. J. Food Microbiol. 2004, 91, 13-18. [CrossRef]

92. Fabrizio, K.A.; Cutter, C.N. Stability of Electrolyzed Oxidizing Water and Its Efficacy against Cell Suspensions of Salmonella Typhimurium and Listeria monocytogenes. J. Food Prot. 2003, 66, 1379-1384. [CrossRef] 
93. Park, H.; Hung, Y.-C.; Kim, C. Effectiveness of Electrolyzed Water as a Sanitizer for Treating Different Surfaces. J. Food Prot. 2002, 65, 1276-1280. [CrossRef]

94. Kimura, M.; Mikami, K.; Hoshikawa, H.; Mori, T.; Kasai, H.; Yoshimizu, M. Effect of rearing using an electrolyzed seawater on reduction of Vibrio parahaemolyticus from sea urchin. Nippon. Suisan Gakkaishi 2006, 72, 1-5. [CrossRef]

95. Ozer, N.P.; Demirci, A. Electrolyzed oxidizing water treatment for decontamination of raw salmon inoculated with Escherichia coli O157:H7 and Listeria monocytogenes Scott A and response surface modeling. J. Food Eng. 2006, 72, 234-241. [CrossRef]

96. Huang, Y.-R.; Hsieh, H.-S.; Lin, S.-Y.; Hung, Y.-C.; Hwang, D.-F. Application of electrolyzed oxidizing water on the reduction of bacterial contamination for seafood. Food Control. 2006, 17, 987-993. [CrossRef]

97. Rahman, S.; Jin, Y.-G.; Oh, D.-H. Combined Effects of Alkaline Electrolyzed Water and Citric Acid with Mild Heat to Control Microorganisms on Cabbage. J. Food Sci. 2010, 75, M111-M115. [CrossRef] [PubMed]

98. Rahman, S.; Jin, Y.-G.; Oh, D.-H. Combination treatment of alkaline electrolyzed water and citric acid with mild heat to ensure microbial safety, shelf-life and sensory quality of shredded carrots. Food Microbiol. 2011, 28, 484-491. [CrossRef]

99. Rahman, S.; Park, J.; Bin Song, K.; Al-Harbi, N.A.; Oh, D.-H. Effects of Slightly Acidic Low Concentration Electrolyzed Water on Microbiological, Physicochemical, and Sensory Quality of Fresh Chicken Breast Meat. J. Food Sci. 2011, 77, M35-M41. [CrossRef]

100. Tango, C.N.; Mansur, A.R.; Oh, D.-H. Fumaric Acid and Slightly Acidic Electrolyzed Water Inactivate Gram Positive and Gram Negative Foodborne Pathogens. Microorganisms 2015, 3, 34-46. [CrossRef]

101. Xu, G.; Tang, X.; Tang, S.; You, H.; Shi, H.; Gu, R. Combined effect of electrolyzed oxidizing water and chitosan on the microbiological, physicochemical, and sensory attributes of American shad (Alosa sapidissima) during refrigerated storage. Food Control. 2014, 46, 397-402. [CrossRef]

102. Jung, S.; Ko, B.S.; Jang, H.-J.; Park, H.J.; Oh, S.-W. Effects of slightly acidic electrolyzed water ice and grapefruit seed extract ice on shelf life of brown sole (Pleuronectes herzensteini). Food Sci. Biotechnol. 2017, 27, 261-267. [CrossRef]

103. Xie, J.; Sun, X.; Pan, Y.; Zhao, Y. Combining basic electrolyzed water pretreatment and mild heat greatly enhanced the efficacy of acidic electrolyzed water against Vibrio parahaemolyticus on shrimp. Food Control. 2011, 23, 320-324. [CrossRef]

104. Shiroodi, S.G.; Ovissipour, M.; Ross, C.F.; Rasco, B.A. Efficacy of electrolyzed oxidizing water as a pretreatment method for reducing Listeria monocytogenes contamination in cold-smoked Atlantic salmon (Salmo salar). Food Control. 2016, 60, 401-407. [CrossRef]

105. Rahman, S.M.E.; Ding, T.; Oh, D.-H. Inactivation effect of newly developed low concentration electrolyzed water and other sanitizers against microorganisms on spinach. Food Control. 2010, 21, 1383-1387. [CrossRef]

106. Rahman, S.; Khan, I.; Oh, D.-H. Electrolyzed Water as a Novel Sanitizer in the Food Industry: Current Trends and Future Perspectives. Compr. Rev. Food Sci. Food Saf. 2016, 15, 471-490. [CrossRef] [PubMed]

107. Hierro, E.; Ganan, M.; Barroso, E.; Fernández, M. Pulsed light treatment for the inactivation of selected pathogens and the shelf-life extension of beef and tuna carpaccio. Int. J. Food Microbiol. 2012, 158, 42-48. [CrossRef] [PubMed]

108. Monteiro, M.L.G.; Mársico, E.T.; Mutz, Y.D.S.; Castro, V.S.; Moreira, R.V.D.B.P.; Álvares, T.D.S.; Conte-Junior, C.A. Combined effect of oxygen-scavenger packaging and UV-C radiation on shelf life of refrigerated tilapia (Oreochromis niloticus) fillets. Sci. Rep. 2020, 10, 4243. [CrossRef]

109. Yu, D.; Zhao, W.; Yang, F.; Jiang, Q.; Xu, Y.; Xia, W. A strategy of ultrasound-assisted processing to improve the performance of bio-based coating preservation for refrigerated carp fillets (Ctenopharyngodon idellus). Food Chem. 2020, 345, 128862. [CrossRef]

110. Antunes-Rohling, A.; Astráin-Redín, L.; Calanche-Morales, J.; Marquina, P.; Beltrán, J.; Raso, J.; Cebrián, G.; Álvarez, I. Ecoinnovative possibilities for improving the quality of thawed cod fillets using high-power ultrasound. Food Control. 2020, 121, 107606. [CrossRef]

111. Pedrós-Garrido, S.; Condon_Abanto, S.; Beltrán, J.; Lyng, J.; Brunton, N.; Bolton, D.; Whyte, P. Assessment of high intensity ultrasound for surface decontamination of salmon (S. salar), mackerel (S. scombrus), cod (G. morhua) and hake (M. merluccius) fillets, and its impact on fish quality. Innov. Food Sci. Emerg. Technol. 2017, 41, 64-70. [CrossRef]

112. Khazandi, M.; Deo, P.; Ferro, S.; Venter, H.; Pi, H.; Crabb, S.; Amorico, T.; Ogunniyi, A.D.; Trott, D.J. Efficacy evaluation of a new water sanitizer for increasing the shelf life of Southern Australian King George Whiting and Tasmanian Atlantic Salmon fillets. Food Microbiol. 2017, 68, 51-60. [CrossRef]

113. Al-Qadiri, H.M.; Al-Holy, M.A.; Shiroodi, S.G.; Ovissipour, M.; Govindan, B.N.; Al-Alami, N.; Sablani, S.S.; Rasco, B. Effect of acidic electrolyzed water-induced bacterial inhibition and injury in live clam (Venerupis philippinarum) and mussel (Mytilus edulis). Int. J. Food Microbiol. 2016, 231, 48-53. [CrossRef]

114. Ovissipour, M.; Shiroodi, S.G.; Rasco, B.; Tang, J.; Sablani, S.S. Electrolyzed water and mild-thermal processing of Atlantic salmon (Salmo salar): Reduction of Listeria monocytogenes and changes in protein structure. Int. J. Food Microbiol. 2018, $276,10-19$. [CrossRef] [PubMed]

115. Wang, J.J.; Lin, T.; Li, J.B.; Liao, C.; Pan, Y.J.; Zhao, Y. Effect of acidic electrolyzed water ice on quality of shrimp in dark condition. Food Control. 2014, 35, 207-212. [CrossRef]

116. Zhang, B.; Ma, L.; Deng, S.-G.; Xie, C.; Qiu, X.-H. Shelf-life of pacific white shrimp (Litopenaeus vannamei) as affected by weakly acidic electrolyzed water ice-glazing and modified atmosphere packaging. Food Control. 2015, 51, 114-121. [CrossRef]

117. Al-Holy, M.A.; Rasco, B.A. The bactericidal activity of acidic electrolyzed oxidizing water against Escherichia coli O157:H7, Salmonella Typhimurium, and Listeria monocytogenes on raw fish, chicken and beef surfaces. Food Control. 2015, 54, 317-321. [CrossRef] 
118. Xuan, X.-T.; Fan, Y.-F.; Ling, J.-G.; Hu, Y.; Liu, D.-H.; Chen, S.; Ye, X.-Q.; Ding, T. Preservation of squid by slightly acidic electrolyzed water ice. Food Control. 2017, 73, 1483-1489. [CrossRef]

119. Rajkowski, K.T.; Sommers, C.H. Effect of Anolyte on Background Microflora, Salmonella, and Listeria monocytogenes on Catfish Fillets. J. Food Prot. 2012, 75, 765-770. [CrossRef] [PubMed]

120. Lin, T.; Wang, J.J.; Li, J.B.; Liao, C.; Pan, Y.J.; Zhao, Y. Use of Acidic Electrolyzed Water Ice for Preserving the Quality of Shrimp. J. Agric. Food Chem. 2013, 61, 8695-8702. [CrossRef] [PubMed]

121. Li, P.; Chen, Z.; Tan, M.; Mei, J.; Xie, J. Evaluation of weakly acidic electrolyzed water and modified atmosphere packaging on the shelf life and quality of farmed puffer fish (Takifugu obscurus) during cold storage. J. Food Saf. 2020, 40. [CrossRef]

122. Zhao, Y.-M.; De Alba, M.; Sun, D.-W.; Tiwari, B. Principles and recent applications of novel non-thermal processing technologies for the fish industry-A review. Crit. Rev. Food Sci. Nutr. 2018, 59, 728-742. [CrossRef] [PubMed] 